Working Paper n. 10 - 2010

\title{
REGIONAL ECONOMIC DIVIDE AND THE ROLE OF TECHNOLOGICAL SPILLOVERS IN ITALY. EVIDENCE FROM MICRODATA
}

Francesco Aiello

Dipartimento di Economia e Statistica

Università della Calabria

Ponte Pietro Bucci, Cubo 1/C

Tel.: +390984 492440

Fax: +390984492421

e-mail: f.aiello@unical.it
Paola Cardamone

Dipartimento di Economia e Statistica

Università della Calabria

Ponte Pietro Bucci, Cubo 1/C

Tel.: +390984 492442

Fax: +390984 492421

e-mail: p.cardamone@unical.it

Maggio 2010

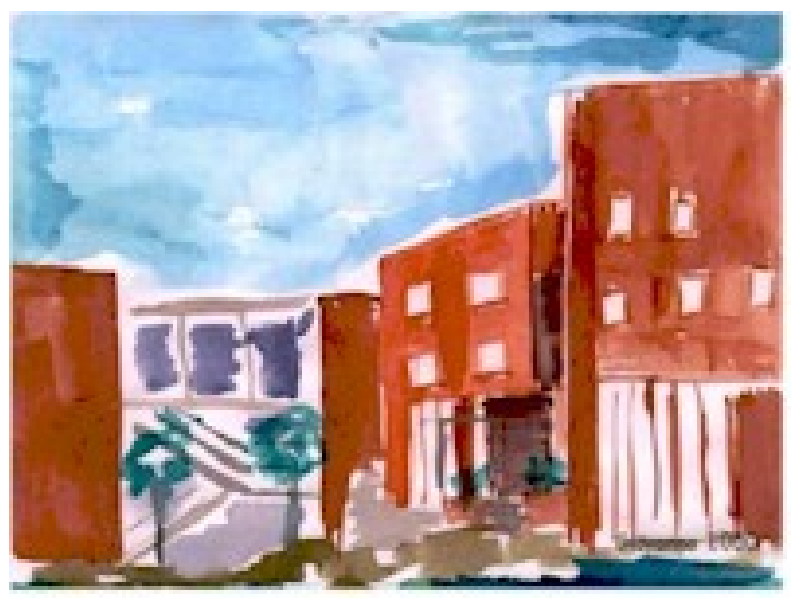




\title{
Regional Economic Divide and the Role of Technological Spillovers in Italy. Evidence from Microdata
}

\author{
Francesco Aiello AND PAOla CARDAMONE \\ (f.aiello@unical.it-p.cardamone@unical.it) \\ University of Calabria - Department of Economics and Statistics \\ I-87036 Arcavacata di Rende (CS), Italy
}

\begin{abstract}
This paper assesses the impact of R\&D efforts on production in the North and Centre-South of Italy by using a panel of 1203 manufacturing firms over the period 1998-2003. The estimations are based on a nonlinear translog production function augmented by a measure of R\&D spillovers. This measure combines the geographical distance between firms, the technological similarity within each pair of firms and the technical efficiency of each firm. The estimation method takes into account the endogeneity of regressors and the potential sample selection issue regarding firms' decision to invest in R\&D. Results show that the external stock of technology exerts a higher impact in the Centre-South of Italy. Finally, it emerges that R\&D capital and R\&D spillovers are substitutes for Northern firms and complements for Centre-Southern firms.
\end{abstract}

Keywords: R\&D spillovers, Italian economic divide, translog production function, technical efficiency.

JEL codes: O33, L29, C23.

\section{Introduction}

In the field of regional economic development, Italy is a particularly interesting case study because it includes both industrialized and less industrialized regions. These regions are geographically clustered, in the sense that the more efficient regions are grouped in the North of the country, while the South of Italy is a case of a lack of industrialization. A large quantity of literature has analyzed the dualism of the Italian economy and, in many cases, this has tested the hypothesis of a process of convergence across Italian regions. Although the evidence produced in this area of research is mixed, a consensus has been reached as regards the fact that there is no absolute convergence (apart from a short period up to the middle of the 1970s), while a certain degree of conditional convergence can be estimated when analyzing the dynamics of Italian regions (Carmeci and Mauro 2002; Cosci and Mattesini, 1997; Paci and Pigliaru, 1995; Paci and Saba, 1998; Bianchi and Menegatti; 1997; Fabiani and Pellegrini; 1997). 
Departing from these results, a great deal of research pays attention to understanding the reasons for the persistency and wideness of regional differences in GDP per capita in Italy. Some authors show that the divide in regional GDP per capita is not related to differences in capital deepening carried out at regional level, but that the main source of the gap is total factor productivity (see, for instance, Aiello and Scoppa 2000; Di Liberto el al. 2008; Maffezzoli 2006). Another strand of literature focuses on the explanations for the regional divide. On this, we in brief reveal that many scholars argue and agree that the economic disparities between South and North of Italy depend on the sizeable differences in such factors as the efficiency of regional social institutions, the level and quality of infrastructure, the agglomeration economies and the working of financial markets (Banca d'Italia 2009; Di Giacinto and Nuzzo 2006; Atzeni and Carboni 2006; Evangelista et al., 2002). Nevertheless, while it has been argued that Italy is far from the technological frontier, little attention has been paid, to the best of our knowledge, to the understanding of the role exerted by $R \& D$ activities at regional level in Italy. Does the role of R\&D activities differ from an area to another? If it does, may we identify the explanation for the different impacts? Is this due to the R\&D effort of each firm or do R\&D spillovers matter?

Starting from these questions, this paper contributes to an explanation of the Italian regional divide by evaluating the role of $\mathrm{R} \& \mathrm{D}$ in the Centre-South of Italy and in the rest of the country. The analysis is made by using data at firm level and departs from the basic idea that a higher level of R\&D investments allows the introduction of new processes and/or new products or the improvement of existing ones, so enhancing profits and/or reducing costs and, as a consequence, increasing productivity. With regards the role of innovative efforts, it is worth noticing that a growing body of literature suggests that $R \& D$ not only directly boosts the profitability of any economic activity but also increases firm absorptive capacity (that is to say the ability of a firm to absorb technology produced by other firms). Again, given that technology is a quasipublic good, the innovative activities undertaken by a firm may benefit other firms, generating spillovers. Therefore, technology available to each firm is a result not only of its innovative activities, but also of the R\&D processes undertaken by others. Taking into account all these considerations, the study aims at evaluating the role of firms' own $R \& D$ and of $R \& D$ spillovers and investigates the relationship of 
substitution/complementarity between internal and external R\&D. Knowing that Italy is characterised by large differences in economic performances from one area to another, the impact of R\&D activities is evaluated by aggregating firms according to their geographical location.

Some micro-econometric studies have recently dealt with technological spillovers (Cincera, 2005; Harhoff, 2000; Jaffe, 1988; Los and Verspagen, 2000; Wakelin, 2001; Medda and Piga, 2004; Adams and Jaffe, 1996; Aiello and Pupo, 2004; Aiello, Cardamone and Pupo, 2005; Aiello and Cardamone, 2005, 2008). Results mainly show that R\&D spillovers positively affect firms' output, although the magnitude of the impact varies from one study to another. ${ }^{1}$ Except for the paper by Aiello and Cardamone (2008), these papers do not address the issue regarding the role of $R \& D$ in different areas of a country. In their paper, Aiello and Cardamone use a translog production function with constant returns to scale (CRS) and compare the impact of R\&D spillovers in the North and in the South of Italy. They show that the effect of R\&D stock on Centre-Southern firms' production is slightly lower, while the effect of R\&D spillovers is markedly higher. However, the output elasticities obtained by Aiello and Cardamone (2008) are sensitive to the measures of R\&D spillovers. This evidence likely depends on the assumption made regarding the CRS of that work.

This paper aims at providing an in-deep analysis of the different innovation strategies implemented by firms in the North and the Centre-South of Italy by introducing three improvements in the empirical setting. The first regards the assumption on the production function, the second concerns the determination of the proxy of R\&D spillovers, whereas the third distinguishing feature of the study refers to the procedure used to estimate the model.

The investigation is carried out by considering a trans-logarithmic production function. The main advantage of the use of this production function is that it does not constraint the elasticity of substitution among inputs to any particular value and, hence, allows us to understand whether inputs (labour, physical and technological capital, R\&D spillovers) are complements or substitutes. This evaluation is particular helpful

\footnotetext{
1 In particular, the output elasticity relative to R\&D spillovers ranges from 0.08 (385 Italian manufacturing firms over the period 1992-1997, Aiello, Cardamone and Pupo, 2005; 573 U.S. firms over the period 1972-1977, Jaffe, 1988) to 0.60 (680 U.S. firms over the period 1977-1991, Los and Verspagen, 2000; 625 large firms around the world over the period 1987-1994, Cincera, 2005).
} 
for a better understanding of the differences in results when one input, such as R\&D spillovers, acts as a public good and is expected to generate positive externality. Along this line, the understanding of the relationship between inputs is really interesting when analysing the Italian regional divide because the level and the type of innovative efforts vary from one area to another. In contrast with Aiello and Cardamone (2008), this paper relaxes the strict assumption of CRS because R\&D spillovers work as a public good and, thus, they introduce positive externalities on firms' costs. From a methodological point of view, a by-product of relaxing the CRS assumption is that the production function is not linear, where the non linearity implies that the returns to scale become a result of the model.

As regards the measure of $R \& D$ spillovers, following the related literature (Griliches, 1979 and 1991), the technological capital of other firms is considered to be the object of the technological transfer; it is further assumed that firms are unable to absorb all external technology and that absorptive capacity differs from one firm to another (Cincera, 2005; Harhoff, 2000; Jaffe, 1988; Los and Verspagen, 2000). ${ }^{2}$ All this implies that technological spillovers can be determined as a weighted sum of other firms' technological capital. As was also done by Aiello and Cardamone (2008), the weighting system used in this study is based on the similarity index which is computed on a set of firm specific variables. However, this paper improves the measure of similarity in order to address the issue relating to direction in the diffusion of technology. We argue that the transfer of technology across firms is related to each firm's efficiency and, in particular, we assume that the more technically efficient a firm is, the greater its capacity to absorb external technology is. The efficiency scores of each firm are retrieved by performing a Data Envelopment Analysis (DEA). ${ }^{3}$ Finally, firms' geographical proximity is considered as another key-factor in the transmission of technology.

\footnotetext{
${ }^{2}$ It is worth noting that scholars disagree about how to weight innovation flows. The most commonly used weights are based either on input-output (I/O) matrices (Wakelin, 2001; Medda and Piga, 2004; Aiello and Pupo, 2004; Aiello, Cardamone and Pupo, 2005; Aiello and Cardamone, 2005) or similarity indices computed considering patent data or R\&D investments (Adams and Jaffe, 1996, Jaffe, 1986 and 1988; Los and Verspagen, 2000; Cincera, 2005; Harhoff, 2000).

3 The DEA was first proposed by Charnes et al. (1978). It consists of a non-parametric approach used to estimate a production function in order to determine the minimum amounts of inputs necessary to produce a given amount of the output. This method differs from stochastic frontiers in that it does not require the specification of a functional form of the production process. In this analysis, the DEA approach is implemented considering a problem oriented to the minimization of inputs and assuming variable returns to scale.
} 
Using a panel of 1,203 manufacturing firms over the period 1998-2003, the estimations have been made considering a system of equations determined by the nonlinear translog production function and the cost share equations. The use of a system of equations allows us to reduce the multicollinearity among regressors and improve the efficiency of estimators. Moreover, in order to control for the endogeneity of regressors, we employ the nonlinear three stage least square estimator (N3SLS). Finally, a two step instrumental variable method (IV) is used to correct for sample selection bias (Wooldridge, 2002): in the first step a probit model which describes the firm's decision to invest in R\&D is estimated; in the second step the fitted probabilities obtained in the first step are used as instrumental variables in the translog estimation.

Results show that the role of external technology is greater in the Centre and South of Italy than in the North of the country. Moreover, the internal and external stocks of R\&D capital are Morishima-substitutes for Northern firms and Morishimacomplements for Central-Southern ones. ${ }^{4}$

The paper is organized as follows. Section 2 discusses the production function specification and presents the system of equations used in the estimations. Section 3 introduces the procedures used to determine the different R\&D spillovers indicators. Section 4 describes data. Section 5 discusses the econometric methods and reports the results. Finally, section 6 concludes.

\section{The translog production function}

The Cobb Douglas production function is the most commonly used functional form to estimate the impact of technological spillovers on output. This functional form imposes that elasticity of substitution between inputs is unity and, hence, does not allow assessment of the substitution/complementarity between inputs, in particular between traditional inputs (labour, physical and technological capital) and the spillovers stock. We use a translog production function (Christensen, Jorgenson and Lau, 1973) and test whether this choice is appropriate. The specification considered is that proposed by Chan and Mountain (1983), and successively corrected by Kim (1992). It does not

\footnotetext{
${ }^{4}$ The Morishima (1967) elasticity of substitution is defined as the percentage change in the ratio of input $\mathrm{k}$ and input $\mathrm{s}$ due to a one percent change in the price of input $\mathrm{s}$, all other prices being constant. If $\mathrm{MES}_{\mathrm{ks}}>0$ then factors $\mathrm{k}$ and $\mathrm{s}$ will be substitutes, whereas if $\mathrm{MES}_{\mathrm{ks}}<0$ they will be complements.
} 
require returns to scale to be constant since the relative parameter $\theta$ is directly estimated. The production function is as follows:

$$
\begin{aligned}
\ln Y_{i t} & =\theta\left(\alpha+\alpha_{L} \ln L_{i t}+\alpha_{K} \ln K_{i t}+\alpha_{C t} \ln C T_{i t}+\alpha_{S p} \ln S p i l l_{i t-1}+\xi_{T} t\right. \\
& +\frac{1}{2} \beta_{L L}\left(\ln L_{i t}\right)^{2}+\frac{1}{2} \beta_{K K}\left(\ln K_{i t}\right)^{2}+\frac{1}{2} \beta_{C t C t}\left(\ln C T_{i t}\right)^{2} \\
& +\frac{1}{2} \beta_{S p S p}\left(\ln S p i l l_{i t-1}\right)^{2}+\frac{1}{2} \delta_{T T}(t)^{2}+ \\
& +\beta_{L K} \ln L_{i t} \ln K_{i t}+\beta_{L C t} \ln L_{i t} \ln C T_{i t}+\beta_{L S p} \ln L_{i t} \ln S p i l l_{i t-1} \\
& +\beta_{K C t} \ln K_{i t} \ln C T_{i t}+\beta_{K S p} \ln K_{i t} \ln S p i l l_{i t-1}+\beta_{C t S p} \ln C T_{i t} \ln S p i l l_{i t-1} \\
& \left.+\gamma_{L T} \ln L_{i t} \cdot t+\gamma_{K T} \ln K_{i t} \cdot t+\gamma_{C t T} \ln C T_{i t} \cdot t+\gamma_{S p T} \ln S p i l l_{i t-1} \cdot t\right) \\
& +\eta_{\mathrm{s}} d p_{s}+\eta_{g} d a_{g}+\varepsilon_{i t}
\end{aligned}
$$

for $i=1, \ldots, N$ firms and $t=1, \ldots, \mathrm{T}$ years, where $Y$ is output, $L$ is labour, $K$ is physical capital, $C T$ is technological capital, Spill is the R\&D spillovers stock and $\mathrm{t}$ is a temporal index. Furthermore, $\mathrm{dp}_{\mathrm{s}}$, with $\mathrm{s}=2,3,4$, are industrial dummies according to the Pavitt classification, da $\mathrm{g}_{\mathrm{g}}$, with $\mathrm{g}=1,2,3$, are territorial dummies, and $\varepsilon_{i t}$ is the error term. ${ }^{5} \mathrm{We}$ consider the usual assumption of symmetry in the translog production function (Christensen et al., 1973; Berndt and Christensen, 1973), so that $\beta_{i j}=\beta_{j i}$.

Output is measured by the value added of firms. Physical capital is measured by the book value of total assets. Labour is given by the number of employees. Furthermore, the stock of technological capital is determined for each firm by current and past investments in R\&D. This stock of capital is used to determine the stock of R\&D spillovers (Spill in eq. [1]) that is available to each firm. Moreover, the stock of spillovers is one-year lagged in order to take into account the plausible assumption according to which there is a temporal lag between the time when the new knowledge becomes available and the time when it is identified, absorbed and used by firms.

In order to verify the validity of the translog production function rather than the Cobb-Douglas, the joint significance of parameters $\beta, \gamma$ and $\delta$ is tested. If they are jointly significant then the Cobb-Douglas will be not adequate. The contrary holds.

\footnotetext{
${ }^{5}$ As regards the industrial dummies, $\mathrm{dp} 1$ is relative to traditional industries, $\mathrm{dp}_{2}$ to large scale industries, $\mathrm{dp}_{3}$ to specialized industries and $\mathrm{dp}_{4}$ to highly technological ones. The control group is $\mathrm{dp}_{1}$, that is the traditional industries. As for the geographical dummies, da $\mathrm{a}_{1}$ relates to the North West, $\mathrm{da}_{2}$ to the North East, $\mathrm{da}_{3}$ to the Centre and $\mathrm{da}_{4}$ to the South of Italy. The control group is $\mathrm{da}_{4}$, which refers to firms located in the South of Italy.
} 
Following Berndt and Christensen (1973) and May and Danny (1979), the equation [1] is estimated as being part of a system of equations which includes the costshare equations. This is because the system of equations allows us to use additional information without increasing the number of parameters to be estimated (Antonioli et al., 2000). Furthermore, it improves the efficiency of estimations and reduces the multicollinearity suspected of being present in equation [1] (Feser, 2004; Lall et al., 2001; Goel, 2002).

Under the assumption of profit maximizing firms, the cost share equations of labour $S_{L}$, physical capital $S_{K}$, technological capital $S_{C T}$ and R\&D spillovers stock $S_{S P}$ are the following:

$$
\begin{aligned}
& S_{L, i t}=\alpha_{L}+\beta_{L L} \ln L_{i t}+\beta_{L K} \ln K_{i t}+\beta_{L C t} \ln C T_{i t}+\beta_{L S p} \ln S p i l l_{i t-1}+\gamma_{L T} \cdot t+u_{L, i t} \\
& S_{K, i t}=\alpha_{K}+\beta_{L K} \ln L_{i t}+\beta_{K K} \ln K_{i t}+\beta_{K C t} \ln C T_{i t}+\beta_{K S p} \ln S p i l l_{i t-1}+\gamma_{K T} \cdot t+u_{K, i t} \\
& S_{C t, i t}=\alpha_{C t}+\beta_{L C t} \ln L_{i t}+\beta_{K C t} \ln K_{i t}+\beta_{C t C t} \ln C T_{i t}+\beta_{C t S p} \ln S p i l l_{i t-1}+\gamma_{C t T} \cdot t+u_{C t, i t}[4] \\
& S_{S p, i t}=\alpha_{S p}+\beta_{L S p} \ln L_{i t}+\beta_{K S p} \ln K_{i t}+\beta_{C t S p} \ln C T_{i t}+\beta_{S p S p} \ln S p i l l_{i t-1}+\gamma_{S p T} \cdot t+u_{S p, i t}
\end{aligned}
$$

Since the sum of input cost shares is assumed to be equal to one and the homogeneity of grade $\theta$ is assumed, i.e. the constraints $\sum_{i} \alpha_{i}=1, \sum_{j} \beta_{i j}=0$ and $\sum_{i} \gamma_{i T}=0$ are imposed, the sum of the error terms of the equations [1-5] is unity for each observation, and, hence, the error variance-covariance matrix is singular. Thus, the estimation of the system of equations formed by eq. [1], [2], [3] and [4] yields estimates of all the parameters. $^{6}$

\section{The determination of $R \& D$ spillovers}

From an empirical perspective, one of the main problems in the analysis of the role of $R \& D$ spillovers regards the determination of technological flows between firms.

The most common approach used to determine R\&D spillovers is to consider a weighted sum of other firms' R\&D capital stock. This approach requires the

\footnotetext{
${ }^{6}$ The labour cost share $S_{L}$ is the total labour cost to the value added. Following Verspagen (1995), we compute $\mathrm{S}_{\mathrm{K}}$ and $\mathrm{S}_{\mathrm{CT}}$ as $\left[\mathrm{P}_{\mathrm{I}}(\delta+\mathrm{r})\right] \mathrm{Z} / \mathrm{V}$ where $\mathrm{P}_{\mathrm{I}}$ is the investment price deflator, $\delta$ is the rate of depreciation (assumed to be equal to $5 \%$ for physical capital and $15 \%$ for technological capital), $r$ is the interest rate (assumed to be $5 \%$ ), $\mathrm{Z}$ is the stock of capital (physical or technological) and $\mathrm{V}$ is the value added.
} 
determination of a weighting system $\boldsymbol{\Omega}$ in which each element $\omega_{i j}$ indicates the proportion of technology produced by firm $j$ and used by firm $i$. Two assumptions should be considered (Griliches, 1979 and 1991): a) it is likely that $\omega_{i j}$ increases when the technological distance between $i$ and $j$ decreases, and b) technological distance does not depend on economic transactions.

Many authors (Jaffe, 1986 and 1988; Griliches, 1979 and 1991; Cincera, 2005; Harhoff, 2000; Inkmann and Pohlmeier 1995; Kaiser, 2002) agree that in order to benefit from external technology firms should develop an adequate absorptive capacity (Cohen and Levinthal, 1989 and 1990). The absorptive capacity is the ability for each firm to identify, assimilate and use external technology in order to improve production/processes or introduce new ones. It is commonly argued that the closer two firms are in technological space, the more they benefit from each other's research efforts. Following the recent literature (Jaffe, 1986 and 1988; Cincera, 2005; Harhoff, 2000; Inkmann and Pohlmeier 1995; Kaiser, 2002; Aiello and Cardamone, 2008), we consider the uncentered correlation metric ${ }^{7}$ which is computed using a set of variables relating to firms' capacity to absorb technology. For each pair of firms $(i, j)$, the uncentered correlation is defined as follows:

$\omega_{i j t}=\frac{\mathbf{X}_{i t} \mathbf{X}_{j t}^{\prime}}{\left(\left(\mathbf{X}_{i t} \mathbf{X}_{i t}^{\prime}\right)\left(\mathbf{X}_{j t} \mathbf{X}_{j t}^{\prime}\right)\right)^{1 / 2}}$

where $\mathbf{X}$ is the set of variables which define the technological similarity at time $\mathrm{t}$ (19982003). Index $\omega_{i j t}$ ranges from zero to one. It is zero when firm $i$ and firm $j$ are not related at all, while it is unity if the k-variables in $X_{i t}$ and $X_{j t}$ are identical. ${ }^{8}$ The variables used to construct the index of similarity are the value added, the skilled (with at least high schooling) and unskilled (with only primary schooling) employees, investments in ICT, ${ }^{9}$ internal and external (for example, using university laboratories)

\footnotetext{
${ }^{7}$ According to Jaffe (1986) and Cincera (2005), the Euclidean measure is "sensitive to the length of the vector. The length depends on the level of concentration of the firm's research activities among the technological classes. With this measure, the more two firms are diversified, the lesser the length of their technological vectors. As a result, these firms will be located in the central region of the technological space. Hence, they will be close to each other even if their technological vectors are orthogonal" (Cincera, 2005, p.12).

${ }^{8}$ The similarity index differs at firm-pair level and this allows us to overcome the strict assumption that firms operating in a given sector have the same absorptive capacity. Such an assumption is commonplace in all the papers that use I/O models and sectoral patent data.

${ }^{9}$ The ICT variable is the sum of hardware, software and telecommunication investments.
} 
$\mathrm{R} \& \mathrm{D}$ investments, and, finally, an index of market concentration. The latter variable is included in order to take into account the characteristics of the industry in which each firm operates and is derived using the Herfindahl-Hirschman index. All variables are normalized with respect to their average in order to take into account the different scales and units of measurement of variables. Variable values are expressed at 2000 real prices.

The similarity index yields a symmetric matrix of weights, that is $\omega_{\mathrm{ijt}}=\omega_{\mathrm{jit}}$. This means that the intensity of the technological flows from firm $i$ to firm $j$ is equal to that observed from firm $\mathrm{j}$ to firm $\mathrm{i}$. This property of the index contrasts with the evidence that direction matters in determining how technology circulates from one firm to another. Therefore, we consider an asymmetric transformation of the similarity index based on an index of technical efficiency obtained from an application of the DEA (Data Envelopment Analysis). In other words, the similarity index is combined with the technical efficiency of each firm, measured in terms of distance from the technological frontier. The DEA is implemented considering a problem orientated to the minimization of inputs and assuming variable returns to scale. The output indicator is the firm's value added while the inputs considered are employees, book value of total assets and technological capital, determined by using the perpetual inventory methods based on R\&D investments and assuming a depreciation rate equal to 15 percent. ${ }^{10}$ Technical efficiency is computed for each firm in the sample for the period 1998-2003.

The index of technical efficiency retrieved from DEA is multiplied by the similarity index (eq. [6]). The underlying hypothesis is that the more efficient a firm is, the more it is able to absorb external technology. In other words, it is assumed that a firm which is close to the efficiency frontier uses technological factors properly in the productive process, so allowing the firm to absorb and use a higher amount of external technology. Thus, a weighting system which considers both technological similarity and technical efficiency is given by the following equations:

$\widetilde{\omega}_{i j t}=\omega_{i j t} \cdot T E_{i t}$

\footnotetext{
${ }^{10}$ Imposing a rate of depreciation equal to 15 percent is a consolidated hypothesis in the empirical analyses dealing with technological capital (Parisi et al., 2006; Hall and Mairesse 1995; Harhoff, 1998; Del Monte and Papagni 2003). In some of these studies (Hall e Mairesse 1995; Harhoff, 1998) a higher depreciation rate is also considered, equal to 25 percent, but empirical results are not substantially different from those obtained imposing a depreciation rate equal to 15 percent.
} 
$\widetilde{\omega}_{j i t}=\omega_{i j t} \cdot T E_{j t}$

where $\mathrm{TE}_{\mathrm{it}}$ and $\mathrm{TE}_{\mathrm{jt}}$ indicate the technical efficiency of firm $i$ and firm $j$, respectively, at time t. $\widetilde{\omega}_{i j t}$ is equal to 1 if the two firms $i$ and $j$ are technologically similar and the firm $i$ is efficient, while it is zero if the two firms $i$ and $j$ are not similar or the firm $i$ is not efficient. The same considerations are valid for $\widetilde{\omega}_{j i t}$. Furthermore, $\widetilde{\omega}_{i j t}$ is equal to $\widetilde{\omega}_{j i t}$ if $\mathrm{TE}_{\mathrm{it}}$ is equal to $\mathrm{TE}_{\mathrm{jt}}$. Otherwise, $\widetilde{\omega}_{i j t}$ and $\widetilde{\omega}_{j i t}$ differ and, thus, the weighting system obtained is asymmetric.

Finally, since a large number of papers deals with the theoretical issues of the nexus between spatial agglomeration and knowledge spillovers (Romer, 1986; Arrow, 1962; Orlando, 2000; Audretsch and Feldman, 2004; Koo, 2005; Bottazzi and Peri, 2002; Aldieri and Cincera, 2009), we include the geographical dimension among factors which determine technological diffusion.

A simple way of weighting the diffusion of innovation among firms located in different areas is to take into account the geographical distance between them. In this paper the distance is measured using the great circle system. Denoting by $D_{i j}$ the geographical distance between the capital towns of the provinces where firms $\mathrm{i}$ and $\mathrm{j}$ operate, the relative distance is given by $d_{i j}=D_{i j} / \max \left(D_{i j}\right)$, where $\max \left(D_{i j}\right)$ is the distance between the two most distant Italian provincial capitals, which are Aosta and Siracusa. A weight of geographical proximity can be computed as follows:

$g_{i j}=\left(1-d_{i j}\right)^{2}$

which is unity when the pair $(i, j)$ is in the same province and is zero when the two firms are located in those provinces with the maximum distance between them. ${ }^{11}$

A proper indicator of technological flow intensities needs to take jointly into account all determinants of technological diffusion, such as technological similarity, technical efficiency and geographical proximity. Since the closer and more similar

\footnotetext{
${ }^{11}$ A quadratic measure of distance is preferred to a linear one in order to take into account the fact that technological flows due to geographical proximity decrease more than proportionately when the distance between firms increases. Indeed, it is reasonable to assume that beyond a certain distance technological flows between firms are only marginally promoted by geographical proximity, as they are also likely to be promoted by other factors such as technological similarity between firms.
} 
firms are, the more they benefit from each other's technology, we average the indexes $\widetilde{\omega}_{i j t}$ and $g_{i j}$ :

$v_{i j t}=\frac{\widetilde{\omega}_{i j t}+g_{i j}}{2}$

The $v_{\mathrm{ijt}}$ index is asymmetric and ranges from zero to one. It is zero when firm $\mathrm{i}$ and firm $\mathrm{j}$ are both geographically distant and technologically dissimilar (or firm $\mathrm{i}$ is not technically efficient), while it is unity if the closeness of the pair $(i, j)$ is unity in both dimensions (technology and geography). ${ }^{12}$

All the weighting systems can be used to determine technological spillovers. For the $i$-th firm and time $t$, the stock of R\&D spillovers (Spill $\left.l_{\mathrm{it}}\right)$ is the weighted sum of R\&D capital of another N-1 firms, that is:

$$
\text { Spill }_{i t}=\sum_{\substack{j=1 \\ j \neq i}}^{N} v_{i j t} C T_{j t} \quad \text { with } \mathrm{i}=1,2, \ldots, \mathrm{N} \quad \text { and } \mathrm{t}=1,2, \ldots, \mathrm{T}
$$

where $v_{\mathrm{ijt}}$ denotes a generic weighting system. Bearing in mind all previous considerations, three stocks of R\&D spillovers are computed. First of all, the spillover stock is computed considering the asymmetric similarity approach, i.e. $v_{\mathrm{ijt}}=\widetilde{\omega}_{i j t}$. Secondly, the flows of innovation are weighted using the geographic proximity $\left(v_{\mathrm{ijt}}=g_{i j}\right)$. Finally, the average of geographical and technological proximity $\left(v_{\mathrm{ijt}}=v_{i j t}\right)$ is considered. The decision to consider just these three weighting systems is due to the fact that, as we indicated above, the unweighted sum of other firms' technological capital $\left(v_{\mathrm{ijt}}=1\right)$ and the symmetric similarity index $\left(v_{\mathrm{ijt}}=\omega_{i j t}\right)$ cannot represent the true intensities of technological diffusion among firms.

\footnotetext{
${ }^{12}$ These very simple indices are an attempt to take into account all of the factors that are likely to affect technological diffusion, in the absence of prior information regarding the relative importance of technological similarity with respect to geographical proximity in the transfer of technology. A natural extension to this study might be the estimation of the translog production function by including two distinct measures of R\&D spillovers as regressors at the same time (the ones obtained using technological similarity and geographical distance). Although this is a fashionable idea, it cannot be implemented for two main reasons. The first one regards the fact that, by using the translog production function, we have the constraint of having to identify the cost share equations (see section 2). In other words, if we use two measures of $R \& D$ spillovers, then we should include, in the system of equations, the cost share equation of one of the two stocks of R\&D spillovers. This is a difficult task, because the costs of R\&D spillovers are not observable. The second reason is that the two spillover indicators are highly correlated and, thus, cannot both be included in the model at the same time.
} 


\section{Data source}

Data used in the empirical analysis come from the 8th and 9th "Indagine sulle imprese manifatturiere" (IMM) surveys carried out by Capitalia. These two surveys cover the period 1998-2003, contain standard balance sheets and collect a great deal of qualitative information from a large sample of Italian firms. ${ }^{13} 1,650$ firms figure in both surveys, but after data cleaning we obtain a panel of 7,218 observations, with large $\mathrm{N}(1,203$ cross sections) and small Y (6 years).

Table 1 shows a breakdown of the sample of firms in 2003 . We only present data regarding the last year available as the distribution of firms by size, sector and location is greatly time-invariant (data are available upon request). We split the sample into $R \& D$ performing firms and non-R\&D performing firms. The first group is comprised of firms with positive R\&D investments. In 2003 , there were 430 R\&D performing firms and 773 non-R\&D performing firms. With regards to the geographical location of firms, about two-thirds were located in Northern Italy (445 in the North West and 382 in the North East). The sub-sample of non-R\&D performers is always more numerous than that of R\&D performers. At the 2-digit ATECO industry level, the sample is dominated by firms in the textiles, basic metals and non-electrical machinery industries, while the petroleum refining industry is represented by just 6 firms. In the case of R\&D performers, most firms are located in Northern Italy and are active in the non-electrical and electrical machinery industries. As far as size is concerned, a large number of firms are of small and medium size (Table 1). This is in line with the distribution of the Italian industrial system. ${ }^{14}$

Table 1 also reports labour productivity and physical and technological capital intensities in 2003. Labour productivity is measured as the ratio of value added to employees, whereas capital factor intensity is expressed as the ratio of physical (or R\&D) capital to value added. Data are six-year weighted averages. ${ }^{15}$

\footnotetext{
${ }^{13}$ The $8^{\text {th }}$ survey covers the period $1998-2000$ while the $9^{\text {th }}$ survey refers to the period 2001-2003. Each survey considers more than 4,500 firms; including all Italian manufacturing firms with more than 500 workers and a representative sub-sample of firms with more than 10 workers (stratification used by Capitalia considers location, size and sector of the firm).

14 Italian Institute of Statistics (ISTAT) - 8th General Industry and Service Census (http://dwcis.istat.it/cis/index.htm).

${ }^{15}$ Weights are given by $f_{i}=F_{i t} / \sum_{t=1998}^{2003} \sum_{i=1}^{N} F_{i t}$ where $\mathrm{F}_{\text {it }}$ are the sales of the $i$ th firm at time $t$ $(t=1998, \ldots, 2003)$ belonging to a group sized $N(i=1, \ldots, N)$.
} 
It is worth pointing out that the average value of labour productivity is 67,000 euros for the entire sample of firms and 63,000 euros for R\&D performing ones. Furthermore, output per worker differs with geographical area: it ranges from 90,000 euros for the firms operating in the Centre of Italy to 62,000 euros for those in the Northern regions. ${ }^{16}$

With regards size, the highest labour productivity is found in large firms, while, as far as sectors are concerned, the most productive firms belong to the paper and petroleum industries. Finally, the leather industry accounts for the lowest labour productivity. Moreover, physical capital intensity is 1.31 for the total sample of firms and 1.27 for R\&D performers. What emerges is that physical capital intensity is relatively high for firms located in the North-East and the South and low in other areas. With regards size, we notice that the large R\&D performers register high values of physical capital intensity, while, if we consider the entire sample, firms with 11-50 employees have a higher physical capital intensity than firms with 51-250 employees. At an industry level, physical capital intensity is high for the food and rubber and plastic industries. With reference to the full sample only, physical intensity is also high in the petroleum sector.

Bearing in mind the specific aim of this paper, the analysis of $R \& D$ capital intensity is of great interest. At a national level, it is 0.33 for all R\&D performers; firms operating in the North West of Italy register a value $(0.42)$ which is higher than the national average, while, in the other areas, $R \& D$ intensity is low ( 0.30 in North East, 0.22 in the Centre and 0.10 in the South). R\&D intensity differs greatly when one considers firms' size: it is 0.38 for firms with more than 250 employees, 0.33 for small firms (11-50 workers) and 0.2 for medium sized ones (51-250 employees). Finally, intensity is high in the chemical (0.82), electrical (0.54) and in non-electrical (0.37) sectors and low in the wood (0.04) and paper (0.05) sectors (Table 1). To sum up, it seems that there is no clear relationship between innovation and a firm's productivity, except in the analysis according to size which indicates that larger firms seem to invest

\footnotetext{
${ }^{16}$ These figures are driven by the high level of productivity of one firm with $21-50$ workers operating in the petroleum industry and by two firms with more than 250 workers belonging to the paper sector. If we exclude these firms, the differences in labour productivity decrease. We are not worried about the presence of these outliers because these firms are non-R\&D performing and, hence, they are considered in the estimation of the probability of investing in R\&D (see section 5), but not in the estimation of the translog production function in which logarithms are used and, as a consequence, zero observations are eliminated.
} 
more in $R \& D$. The lack of a marked relationship between productivity and $R \& D$ might be due to the fact that firms which operate in different industries carry out different R\&D activities with different intensities. However, even the divergence between North and South in terms of technological capital intensities does not seem to be as evident in terms of labour productivity.

$<$ Insert Table 1 about here $>$

\section{Estimation methods and results}

Results are obtained by estimating the system of equations [1-4], which is not linear because of the nonlinearity of equation [1]. As a consequence of this, we employ the nonlinear three stage least square estimator (N3SLS). Furthermore, the estimation procedure .controls for sample selection bias. This issue arises because the stock of $R \& D$ capital is determined using $R \& D$ investments and, in many cases, firms do not invest in $\mathrm{R} \& \mathrm{D}$ (zero-investment values). Therefore, we have a sub-sample of firms with positive values for $R \& D$ capital and a sub-sample of firms with zero values for $R \& D$ capital. The log-linearization of equation [1] restricts the sample of firms to the R\&D performing firms, and in so doing, forces us to work with a sample which is no longer random because it ignores the underlying process which leads each firm to invest, or not, in R\&D. It can be shown that if this underlying process is correlated with the primary equation, i.e. the translog specification, then estimates obtained disregarding this issue are biased. The selection process can be modelled using a treatment effect model, where the sample is divided into the treated (the units that participate in a programme, in our case the firms which invest in R\&D) and the untreated (firms which do not invest in $R \& D$ ), and the treatment (investing in $R \& D$ ) is an endogenous process. Following Wooldridge (2002), this issue is addressed by using a two-step instrumental variable (IV) method: in the first step a probit model is considered to explain the decision to invest in $\mathrm{R} \& \mathrm{D}$, and, in the second step, the translog production function is estimated using the fitted probabilities $\left(\hat{G}_{i t}\right)$ derived from the first step as instruments. While all firms (R\&D performing and non-R\&D performing) are used in the first stage, only the R\&D performing group is considered in the second stage. This procedure is 
suitable for two main reasons. First of all, the usual standard errors and test statistics are asymptotically valid and, secondly, no particular specification of the probit model has to be set up (Wooldridge, 2002). ${ }^{17}$

The dependent variable of the probit model is unity if the i-th firm invests in R\&D and is zero if it does not. The regressors of the probit model are the explanatory variables of the production function plus the key determinants of the decision to invest in R\&D, which are selected following the literature on this subject (Leo, 2003; Becker and Pain, 2003; Gustavsson and Poldhal, 2003; Bhattacharya and Bloch, 2004). The determinants considered are human capital, cash flow, investments in ICT, a dummy equal to unity if firm $i$ exports and a set of dummies measuring the geographical location and the economic sector of each firm. ${ }^{18}$

Probit estimation results are presented in the table A.1 of the Appendix. Results show that the probability of investing in $R \& D$ is positively affected by cash flow, human capital and investments in ICT, as well as exports. Furthermore, being located in the North of Italy increases the probability of investing in R\&D.

In order to take into account endogeneity of regressors, besides the fitted probabilities obtained in the first step, in the second step we also consider the following instrumental variables: the one-year lagged rate of growth of human capital, the growth rate of ICT investments, and the one-year lagged value of endogenous variables (labour, physical and technical capital and their squared values).

From a theoretical point of view, the estimated parameters of a translog are not interpretable and, hence, only the implied output elasticities with respect to each input are reported. These elasticities are obtained as a combination of the estimated translog coefficients and the average of input values (Verspagen, 1995; Saal, 2001).

Several tests are carried out in order to verify whether the specification chosen and the estimation method employed are appropriate. An initial test concerns the joint

\footnotetext{
${ }^{17}$ Indicating the treatment indicator by $\mathrm{w}$, which is equal to 1 if there is treatment and 0 otherwise, and the probit specification by $\mathrm{G}\left(\mathrm{x}, \mathrm{z}, \gamma^{*}\right)$, "what we need is that the linear projection of $\mathrm{w}$ onto $[\mathrm{x}, \mathrm{G}(\mathrm{x}, \mathrm{z}$, $\left.\gamma^{*}\right)$ ] actually depends on $\mathrm{G}\left(\mathrm{x}, \mathrm{z}, \gamma^{*}\right)$, where we use $\gamma^{*}$ to denote the plim of the maximum likelihood estimator when the model is mis-specified" (Wooldridge 2002, p. 624).

${ }^{18}$ Human capital is computed by $\exp \left(\varphi_{R} S h\right)$ where Sh is the weighted number of years of schooling ( 8 for primary and middle school, 13 for high school and 18 for bachelor degree), where weights are the number of employees by years of schooling, and $\varphi_{R}$ is the regional rate of returns on education drawn from Ciccone (2004). The cash flow variable is computed as gross profits minus taxes plus depreciation. Finally, the IMM surveys only report information on exports for the last year of each survey, i.e. 2000 and 2003. Thus, we assume that this dummy is constant over each three-year period.
} 
significance of coefficients relative to squared and interaction variables. ${ }^{19}$ A second test regards the CRS hypothesis. In particular, the null hypothesis $H_{0}: \theta=1$ is tested versus the alternative hypothesis that $\theta$ is different from one. Finally, the Hansen test on the validity of instrumental variables and the Breusch-Godfrey test on the serial correlation of error terms are also carried out. Results are presented in tables 2 and 3. The diagnostic tests show, in almost all estimations, the validity of the instrumental variables considered and the absence of first and second order serial correlation. ${ }^{20}$ Furthermore, the F-Fisher test shows that the use of the Cobb-Douglas production function is not adequate, since coefficients of the interaction and squared variables are jointly significant, and the t-Student test computed on the $\theta$ coefficient shows that returns to scale are always significantly higher than one. The latter outcome greatly supports the choosing to relax the hypothesis of CRS and sheds some light on the fact that R\&D spillovers act as a quasi-public good that generates positive externalities.

\subsection{Output elasticities}

This section presents results of output elasticities with respect to each input (table 2). We first present the econometric results for the entire Italian sample of firms. In column 1, elasticities are estimated by considering the asymmetric index of technological similarity to be the weighting system of technological flows (see eq. 7 and 8). Column 2 refers to the outcomes obtained using the index of geographical proximity (eq. 9). The final output elasticities (column 3) are obtained by averaging the asymmetric technological similarity index and the geographical proximity measure (eq. 10).

An initial outcome is that all the output elasticities are positive and highly significant. As for conventional inputs, it emerges that the output elasticities relative to labour and physical capital are close to those derived from a neoclassical production function. Indeed, output elasticity relative to labour ranges from 0.61 to 0.64 , while

\footnotetext{
${ }^{19}$ The null hypothesis is:

$H_{0}=\beta_{L K}=\beta_{L C t}=\beta_{L S p}=\beta_{K C t}=\beta_{K S p}=\beta_{C t S p}=\beta_{L L}=\beta_{K K}=\beta_{C t C t}=\beta_{S p S p}=\delta_{T T}=\gamma_{T L}=\gamma_{T K}=\gamma_{T C t}=\gamma_{T S p}=0$ while the alternative hypothesis is that coefficients are jointly different than zero.

${ }^{20}$ The Hansen test rejects the null hypothesis of the validity of instrumental variables at 5 percent and 1 percent in the estimates for North-Western firms with asymmetric similarity index (table 3, column 1) and geographical measure (table 3, column 2) while the null hypothesis cannot be rejected at 1 percent in the estimates for North-Western firms with asymmetric technological and geographical index (table 3, column 3) and for North-Eastern firms with asymmetric technological weighting system (table 3, column 4). In all the other cases, the null hypothesis cannot be rejected at either 1 or 5 percent.
} 
output elasticity relative to physical capital varies from 0.19 to 0.23 . As regards the role of firms' own R\&D, results show that output elasticity is 0.14 , except in column 1 (0.17). This evidence is similar to that obtained in some papers aimed at assessing the impact of R\&D capital on firms' production (Mairesse and Hall, 1996; Hall and Mairesse, 1995; Harhoff, 1998; Aiello, Cardamone and Pupo, 2005).

The magnitude of the impact of R\&D spillovers on firms' production is high. In particular, considering the geographical weighting systems of technological flows, output elasticity relative to $R \& D$ spillovers is 0.32 (column 2$){ }^{21}$ Using an asymmetric index of technological capital (column 1), this elasticity diminishes to 0.08 . In this case, it may be noticed that the McElroy R-squared, which measures the goodness of fit of the system of equations, is slightly higher than in the other estimations. Thus, it seems that using the asymmetric technological index improves the model specification. Finally, considering the average of the asymmetric similarity index and geographical proximity measure (column 3 ), the output elasticity relative to $R \& D$ spillovers is still high and equal to $0.29{ }^{22}$ To sum up, these results confirm the hypothesis that R\&D spillovers significantly affect Italian firms' production, albeit the output elasticities vary according to the procedure used to weight the technological flows.

Table 3 reports the estimated elasticities obtained by dividing the sample according to geographical area. Some of the results displayed are analogous to those obtained for the entire sample of firms. To be more precise, we find that the effect of labour on production does not substantially differ among Italian regions. Moreover, while internal R\&D stock has a slightly higher effect on firms' production in the North than in the Centre-South of Italy, the impact of physical capital is slightly higher in the case of Centre-Southern firms than Northern ones.

As regards $R \& D$ spillovers, we find external $R \& D$ stocks exhibit a higher effect on Centre-Southern firms' production than on Northern ones. Output elasticity with respect to R\&D spillovers which combine asymmetric technological and geographic

\footnotetext{
${ }^{21}$ When we consider symmetric weighting systems of technological flows (the unweighted sum of firms' technological capital and the symmetric similarity index), results are not substantially different from those obtained when we use the geographical proximity measure: output elasticity relative to R\&D spillovers is equal to 0.34 if the unweighted sum of technological capital of other firms is considered and to 0.35 in the case of symmetric similarity index. Results obtained using these two symmetric weighting systems are not reported but are available upon request.

${ }^{22}$ This result is similar to that obtained by Cincera (2005) for a sample of 625 large firms throughout the world over the period 1987-1994, while Los and Verspagen (2002) obtain a higher value (equal to 0.56) for a sample of 680 U.S. manufacturing firms over the period 1977-1981.
} 
proximities is 0.35 for firms operating in the Centre-South, while it is 0.24 and 0.28 for firms in the North-East and North-West of Italy, respectively.

All this evidence suggests that innovative efforts play a significant role in determining the output of Italian manufacturing firms. In addition we find relevant differences in the impact according to the source (internal or external) of R\&D and to the geographical area. Limiting the discussion to the outcomes obtained by combining the technological and geographical issues of the transfers of knowledge, we find that the elasticity of spillovers is, in the Centre-South of Italy 0.34 , i.e. roughly threefold the elasticity (0.12) of firms' own R\&D. We empirically show that Italian manufacturing firms get substantial gains from the technology they absorb and the differences in results according to geographical area are due to several reasons, some of which are related to the level of innovative efforts made by Italian manufacturing firms. The results are not surprising if inputs relating to $R \& D$ exhibit initially increasing and then decreasing marginal returns. In this case the impact of an increase of $R \& D$ is expected to be high, provided that the use of the relative input is extremely low. A likely explanation for the difference between the role of internal and external $R \& D$ is that most Italian firms are characterized by weak technological performances and have an innovative strategy mainly aimed at imitating rather than innovating. This particularly holds in the Centre-South of Italy, where R\&D carried out by each firm is orientated towards establishing a threshold of activities which is both low enough to exert a direct meaningful high effect on production, and, at the same time, high enough to allow the absorption of external technology. Knowing that adopting technology is easier than innovating, the strategy pursued by Italian firms, and in particular by Central and Southern firms, is to gain great advantage by acquiring the maximum level of external technology. From a normative perspective, this evidence indicates that, within the policy agenda, priority should be given to $R \& D$ activities. Any action aimed at increasing each firm's absorptive capacity and fostering the diffusion of technology would be highly effective because of firms' tendency to imitate. Again, the effect of these policies would be great because the system of firms as a whole has a very low level of initial R\&D capital.

$<$ Insert Table 2 about here $>$ 


\subsection{Elasticity of substitution}

The translog production function allows evaluation of the degree of substitution or complementarity among inputs. This is done considering the technical and the Morishima (1967) elasticities of substitution..$^{23,24}$ The determination of elasticities of substitution is limited to the case of the asymmetric technological and geographical index (column 3 in table 2 and columns 3, 6 and 9 in table 3). Table 4 shows the technical and Morishima (1967) elasticities of substitution, which are computed by considering the average of the variables. Furthermore, a test which verifies whether elasticities of substitution are significantly different from one is reported. Test results show that elasticities of substitution are always significantly different from one, and, thus, it is confirmed that in this analysis the use of a Cobb-Douglas production function is not appropriate.

With regards the elasticity of technical substitution, it may be noticed that, in the short run, an increase of 1 percent in the use of labour implies an increase of 3 percent in the use of physical capital, 4 percent in technological capital and 2 percent in the use of R\&D spillovers. Moreover, with regards R\&D spillovers, an increase of 1 percent in technology absorbed by other firms implies an increase of about 1.4 percent in the use of physical capital and 2 percent in technological capital.

As far as the Morishima elasticity of substitution is concerned, it emerges that it is almost always positive. In particular, when considering traditional inputs, higher elasticities of substitution are observed for labour and physical capital and for

\footnotetext{
${ }^{23}$ The Technical Elasticity of Substitution (TES) indicates the percentage change in the use of a production factor in response to an exogenous shock from the supply of another input. In other words, it quantifies how much the reduction of 1 per cent of $\mathrm{s}$ forces a rise in factor $\mathrm{k}$ in order to keep the level of production constant in the short term. In the case of the translog production function, it can be shown that the technical elasticity of substitution may be expressed as follows: $T E S_{k s}=\frac{\alpha_{s}+\beta_{s s} \ln X_{s}+\sum_{i \neq s} \beta_{i s} \ln X_{i}+\gamma_{s T} t}{\alpha_{k}+\beta_{k k} \ln X_{k}+\sum_{i \neq k} \beta_{i k} \ln X_{i}+\gamma_{k T} t}$. This equation indicates that the technical elasticity of substitution between inputs $k$ and $s$ is inversely related to their output elasticities. Furthermore, the TES index is the inverse of $\mathrm{TES}_{\mathrm{sk}}$, and both are always positive.

${ }^{24}$ It should be noted that the Morishima elasticity of substitution is not symmetrical: two factors, $\mathrm{k}$ and s, can be complements when the changes in $\mathrm{p}_{\mathrm{s}}$ are considered, and substitutes when one considers the changes in $\mathrm{p}_{\mathrm{k}}$. In the case of the translog production function, MES is equal to: $M E S_{k s}=\frac{\beta_{k s}^{*}}{S_{k}}-\frac{\beta_{s s}^{*}}{S_{s}}+1$.
} 
technological capital and labour with respect to labour price. Furthermore, the Morishima elasticity of substitution indicates that technological and physical capital are complements with respect to the physical capital price. In particular, an increase of 1 percent in the price of physical capital implies a decrease of about 0.12 percent in the R\&D capital/physical capital ratio.

As far as spillovers are concerned, we find that an increase of 1 percent in the cost of external technology implies an equivalent increase in the physical capital/spillovers and technological capital/spillovers ratios. Hence, an increase in the cost of external technology implies an increase in the use of physical and technological capital. Evidently, this effect on firms' own capital (physical and technological) is to compensate the decrease in the use of $R \& D$ spillovers caused by the higher price of external technology.

When splitting the sample of firms according to geographical area, we find some relevant differences concerning substitution elasticities. In particular, firms located in the Centre-South of Italy register a lower value of technical elasticities of substitution for physical capital and labour (2.96), physical and technological capital (0.55), spillovers and labour (1.77) and spillovers and technological capital (0.37). ${ }^{25}$

With regards to Morishima elasticity, physical and technological capital are complementary with respect to technological capital price (Morishima elasticity is equal to -0.31) for the North-Eastern firms while they are substitutes for the Central-Southern ones. However, technological and physical capital are only complementary with respect to the price of physical capital in the Centre-South of the country. Moreover, labour and technological capital are complementary for firms located in the Centre-South whatever the input price considered. Moreover, results show that, for Centre-Southern firms, technological capital is complementary to other inputs with respect to the price of the $R \& D$ stock. This means that if the cost of R\&D capital decreases, then Centre-Southern firms increase the use of labour, physical capital and external technology. From this point of view, policies aimed at reducing the cost of implementing $R \& D$ seem to

\footnotetext{
${ }^{25}$ Since the elasticity of substitution for inputs $s$ and $k$ is the inverse of that between inputs $k$ and $s$ (see note 24), firms located in the Centre-South of Italy present higher elasticity of technical substitution than other firms do for technological and physical capital (1.83), labour and spillovers (0.56), and technological capital and spillovers (2.67).
} 
provide more benefits to Centre-Southern enterprises in terms of expansion of productive capacity.

Finally, unlike what was observed for the North of the country, technological capital and R\&D spillovers are complementary in the Centre-South. This means, for instance, that an increase of 10 per cent in the price of R\&D capital yields a decrease of 4.5 per cent in the $R \& D$ spillovers/R\&D capital ratio. In other words, if the price of firms' own R\&D increases, then the firms operating in the Centre-Southern regions will reduce the relative use of external technology with respect to internal R\&D capital. This fact is coherent with the earlier discussion about the sense of R\&D capital in the Centre and in the South of the country. The effect of an increase in the cost of internal $\mathrm{R} \& \mathrm{D}$ is not limited to the mere reduction in the use of that input, but this restricts firms' absorptive capacity and, thus, tends to reduce the quantity of external technology used by firms. All this is also a consequence of the imitative characteristics of CentreSouthern firms' innovating activities, which are mainly aimed at the purchasing of machinery and plant (Osservatorio ENEA, 2006). Hence, it is likely that spillovers absorbed by Centre-Southern firms are mainly constituted by rent spillovers, which arise because quality improvements in intermediate and capital goods resulting from R\&D investments are not fully captured in their prices. ${ }^{26}$ In this sense, a higher price of technological capital should increase the price of technologically advanced goods and, thus, the absorption of rent spillovers.

$<$ Insert Table 4 about here $>$

\section{Concluding remarks}

The aim of this paper is to assess the role of internal and external R\&D in Italian manufacturing production. In particular, it provides new elements of evaluation to better understand the differences between firms located in the North and in the Centre-South of Italy.

From a methodological point of view, the study is carried out by estimating a nonlinear translog production function, where $R \& D$ spillovers is an input determined by proposing an asymmetric transformation of the uncentered correlation. This

\footnotetext{
${ }^{26}$ Rent spillovers occurs because of competition and the impossibility of perfect price discrimination.
} 
transformation is made by using a technical efficiency index retrieved from a DEA analysis.

Using a panel data of 1,203 manufacturing firms over the period 1998-2003, we estimate the nonlinear translog specification through the 2-step IV estimator in order to take into account both sample selection and endogeneity issues. In the first step the selection process that leads firms to invest or not in R\&D is modelled. In the second step, the nonlinear translog equation together and the cost-share equations are estimated using the nonlinear 3SLS estimator.

Results show that Central-Southern firms present a slightly lower output elasticity relative to their own $R \& D$ capital and a considerably higher output elasticity relative to R\&D spillovers. As far as Morishima elasticities are concerned, we find that, except for technological and physical capital, which are complements, all other inputs are substitutes. However, some differences in results have been observed between the different areas of the country. In particular, a marked difference is observed in the elasticity of substitution between $R \& D$ spillovers and internal $R \& D$ capital: $R \& D$ spillovers and technological capital are substitutes for Northern firms and complements for those in the Centre-South of Italy. This outcome might be a consequence of the technological strategy made by Centre-Southern firms, which mainly adopt external technology through purchases of highly technological machinery and plant (Osservatorio ENEA, 2006).

In terms of policy implications, the low level of innovative activities observed in Italy, particularly in the Centre-South of the country, requires public intervention in favour of R\&D. For instance, policies orientated towards lowering the cost of $R \& D$ would cause an increase in the production and adoption of technology at plant level with clear results in terms of firm performance. At the same time, an increase of R\&D endowment determines an increase in the firm's absorptive capacity and, hence, determines higher gains from adopting a higher level of external technology. This is particularly true in the Centre-South of Italy where firms benefit more from R\&D spillovers than in the North of the country. Moreover, as Southern firms carry out their innovative activities in isolation (Evangelista et al., 2002) and given that Italy is, on average, a follower in the world's production of technology, regional policy might be aimed at improving R\&D interactions among firms and between firms and public 
institutions (research centres, public laboratories, universities, etc.) in order to build up a network of R\&D-oriented firms necessary to allow the South of Italy to be placed near to the technological frontier and continue to gain great advantages from absorbing technology developed by others. 
Table 1. Breakdown of the sample of firms, labour productivity and factor intensity in Italian manufacturing firms by industry, area and size in 2003 (weighted average*)

\begin{tabular}{|c|c|c|c|c|c|c|c|}
\hline & \multicolumn{3}{|c|}{ Total sample } & \multicolumn{4}{|c|}{$\mathrm{R} \& \mathrm{D}$ performing firms } \\
\hline & $\begin{array}{l}\text { No of } \\
\text { firms }\end{array}$ & $\mathbf{Y} / \mathbf{L} * *$ & $\mathbf{K} / \mathbf{Y} * *$ & $\begin{array}{l}\text { No of } \\
\text { firms }\end{array}$ & $\mathbf{Y} / \mathbf{L}^{* *}$ & $\mathbf{K} / \mathbf{Y} * *$ & $\mathrm{CT} / \mathbf{Y}^{* *}$ \\
\hline $\begin{array}{l}\text { Sector } \\
\text { Food, Beverages \& Tobacco } \\
\text { Textiles \& Apparel } \\
\text { Leather } \\
\text { Wood Products \& Furniture } \\
\text { Paper, Paper Prod. \& Printing } \\
\text { Petroleum Refineries \& Product } \\
\text { Chemicals } \\
\text { Rubber \& Plastic Products } \\
\text { Non-Metallic Mineral Products } \\
\text { Basic Metal \& Fab. Met. Prod. } \\
\text { Non-Electrical Machinery } \\
\text { Electrical Machinery and Electronics } \\
\text { Motor vehicles \& Other Transport } \\
\text { Equipment } \\
\text { Other Manufacturing Industries }\end{array}$ & $\begin{array}{c}103 \\
148 \\
50 \\
47 \\
68 \\
6 \\
55 \\
65 \\
81 \\
193 \\
174 \\
100 \\
\\
27 \\
86\end{array}$ & $\begin{array}{c}53 \\
55 \\
41 \\
44 \\
147 \\
229 \\
73 \\
67 \\
72 \\
62 \\
63 \\
51 \\
55 \\
40\end{array}$ & $\begin{array}{l}3.12 \\
1.19 \\
1.09 \\
1.43 \\
0.82 \\
1.82 \\
0.83 \\
1.79 \\
1.72 \\
1.36 \\
0.80 \\
0.85 \\
\\
\\
1.48 \\
0.91\end{array}$ & $\begin{array}{c}25 \\
51 \\
15 \\
10 \\
10 \\
1 \\
29 \\
27 \\
19 \\
42 \\
102 \\
61 \\
\\
10 \\
28\end{array}$ & $\begin{array}{c}56 \\
62 \\
46 \\
51 \\
133 \\
85 \\
74 \\
73 \\
71 \\
55 \\
64 \\
51 \\
59 \\
43\end{array}$ & $\begin{array}{l}3.60 \\
1.09 \\
1.40 \\
1.24 \\
0.82 \\
0.69 \\
0.75 \\
1.61 \\
1.41 \\
1.34 \\
0.81 \\
0.87 \\
\\
1.29 \\
0.97\end{array}$ & $\begin{array}{l}0.10 \\
0.14 \\
0.09 \\
0.04 \\
0.05 \\
0.14 \\
0.82 \\
0.37 \\
0.10 \\
0.35 \\
0.37 \\
0.54 \\
\\
0.23 \\
0.19\end{array}$ \\
\hline $\begin{array}{l}\text { Size } \\
\text { 11-20 Employees } \\
21-50 \text { Employees } \\
\text { 51-250 Employees } \\
>250 \text { Employees }\end{array}$ & $\begin{array}{c}452 \\
440 \\
242 \\
69\end{array}$ & $\begin{array}{l}52 \\
58 \\
55 \\
79\end{array}$ & $\begin{array}{l}1.27 \\
1.27 \\
1.18 \\
1.38\end{array}$ & $\begin{array}{l}103 \\
139 \\
138 \\
50\end{array}$ & $\begin{array}{l}53 \\
56 \\
56 \\
67\end{array}$ & $\begin{array}{l}0.91 \\
1.00 \\
1.09 \\
1.40\end{array}$ & $\begin{array}{l}0.33 \\
0.25 \\
0.23 \\
0.38\end{array}$ \\
\hline $\begin{array}{l}\text { Area } \\
\text { North West } \\
\text { North East } \\
\text { Centre } \\
\text { South }\end{array}$ & $\begin{array}{l}445 \\
382 \\
227 \\
149\end{array}$ & $\begin{array}{l}61 \\
62 \\
90 \\
68\end{array}$ & $\begin{array}{l}1.14 \\
1.40 \\
1.06 \\
2.12\end{array}$ & $\begin{array}{c}177 \\
153 \\
64 \\
36\end{array}$ & $\begin{array}{l}62 \\
63 \\
64 \\
66\end{array}$ & $\begin{array}{l}1.08 \\
1.52 \\
1.15 \\
1.32\end{array}$ & $\begin{array}{l}0.42 \\
0.30 \\
0.22 \\
0.10\end{array}$ \\
\hline Total & 1203 & 67 & 1.31 & 430 & 63 & 1.27 & 0.33 \\
\hline
\end{tabular}

Source: Our calculation from data by Capitalia $(2002 ; 2005)$.

Notes: * Weights are expressed as the sales of the $\mathrm{i}$-th firm in relation to the aggregate sales of the group. $* * \mathrm{Y} / \mathrm{L}=\mathrm{Value}$ added/employee (in .000 of Euro); K/Y=Physical capital/Value added; CT/Y=Technological capital/Value added. 
Table 2 Output elasticities for Italian manufacturing firms. N3SLS estimations (1998-2003).

\begin{tabular}{|c|c|c|c|c|c|c|}
\hline \multirow{2}{*}{$\begin{array}{l}\text { Inputs } \\
\mathrm{L}\end{array}$} & \multicolumn{2}{|c|}{$\begin{array}{l}\text { Asymmetric } \\
\text { Technol. Spill. } \\
\text { Column } 1 \\
v_{\mathrm{ij}}=\widetilde{\omega}_{i j}\end{array}$} & \multicolumn{2}{|c|}{$\begin{array}{c}\text { Geograph. Spill. } \\
\text { Column } 2 \\
v_{\mathrm{ij}}=\mathrm{g}_{\mathrm{ij}}\end{array}$} & \multicolumn{2}{|c|}{$\begin{array}{c}\text { Asymmetric } \\
\text { Technol. And } \\
\text { Geograph. Spill. } \\
\text { Column } 3 \\
v_{\mathrm{ij}}=v_{i j}\end{array}$} \\
\hline & $\begin{array}{l}0.6384 \\
(.00062)\end{array}$ & $* * *$ & $\begin{array}{l}0.6061 \\
(.00047)\end{array}$ & $* * *$ & $\begin{array}{l}0.6240 \\
(.0005)\end{array}$ & $* * *$ \\
\hline $\mathbf{K}$ & $\begin{array}{l}0.2310 \\
(.00027)\end{array}$ & $* * *$ & $\begin{array}{l}0.1904 \\
(.00023)\end{array}$ & $* * *$ & $\begin{array}{l}0.1997 \\
(.00023)\end{array}$ & $* * *$ \\
\hline CT & $\begin{array}{l}0.1688 \\
(.0002)\end{array}$ & $* * *$ & $\begin{array}{l}0.1379 \\
(.00016)\end{array}$ & $* * *$ & $\begin{array}{l}0.1425 \\
(.00017)\end{array}$ & $* * *$ \\
\hline SPILL & $\begin{array}{l}0.0760 \\
(.00117) \\
\end{array}$ & $* * *$ & $\begin{array}{l}0.3183 \\
(.0012) \\
\end{array}$ & $* * *$ & $\begin{array}{l}0.2867 \\
(.00123) \\
\end{array}$ & $* * *$ \\
\hline Returns to scale & $\begin{array}{l}1.133 \\
(.00135) \\
\end{array}$ & $* * *$ & $\begin{array}{l}1.278 \\
(.00116) \\
\end{array}$ & $* * *$ & $\begin{array}{r}1.274 \\
(.00121) \\
\end{array}$ & $* * *$ \\
\hline $\begin{array}{l}\text { Number of obs. } \\
\text { MC-ELROY R-squared }\end{array}$ & $\begin{array}{l}1083 \\
0.53\end{array}$ & & $\begin{array}{l}1083 \\
0.51\end{array}$ & & $\begin{array}{l}1083 \\
0.51\end{array}$ & \\
\hline t-test $H_{0}: \theta=1$ & 98.07 & $* * *$ & 240.63 & $* * *$ & 226.15 & $* * *$ \\
\hline F-test $H_{0}: \beta, \gamma, \delta=0$ & 129.12 & $* * *$ & 144.79 & $* * *$ & 143.74 & $* * *$ \\
\hline Hansen J-test & 5.67 & & 5.04 & & 6.84 & \\
\hline p-value & 0.129 & & 0.169 & & 0.077 & \\
\hline BG-test [AR(1)] & 0.34 & & 8.83 & & 0.20 & \\
\hline BG-test [AR(2)] & 2.32 & & 5.94 & & 1.31 & \\
\hline
\end{tabular}

Notes: Standard errors reported in brackets. $(* * *)$ denotes statistical significance at the $1 \%$ level. The instrumental variables are the one-year lagged values of the endogenous regressors (labour, physical and technological capital, and their squared value), fitted probabilities obtained from the probit estimates in the first step, one-year lagged growth rate of human capital, and the growth rate of ICT investments. 
Table 3 Output elasticities for the Italian manufacturing firms by area. N3SLS estimations (1998-2003).

\begin{tabular}{|c|c|c|c|c|c|c|c|c|c|c|c|c|c|c|c|c|c|c|}
\hline \multirow{3}{*}{$\begin{array}{l}\text { Output Elasticity } \\
\text { L }\end{array}$} & \multicolumn{6}{|c|}{ NORTH-WEST } & \multicolumn{6}{|c|}{ NORTH-EAST } & \multicolumn{6}{|c|}{ CENTRE-SOUTH } \\
\hline & \multicolumn{2}{|c|}{$\begin{array}{l}\text { Asymmetric } \\
\text { Technol. } \\
\text { Spill. } \\
\text { Column } 1 \S \\
v_{\mathrm{ij}}=\widetilde{\omega}_{i j}\end{array}$} & \multicolumn{2}{|c|}{$\begin{array}{l}\text { Geograph. } \\
\text { Spill. } \\
\text { Column } 2 \S \\
v_{\mathrm{ij}}=g_{i j}\end{array}$} & \multicolumn{2}{|c|}{$\begin{array}{c}\text { Asymmetric } \\
\text { Technol. And } \\
\text { Geograph. } \\
\text { Spill. } \\
\text { Column } 3 \S \\
v_{\mathrm{ij}}=v_{i j}\end{array}$} & \multicolumn{2}{|c|}{$\begin{array}{l}\text { Asymmetric } \\
\text { Technol. Spill. } \\
\begin{array}{c}\text { Column } 4 \\
v_{\mathrm{ij}}=\widetilde{\omega}_{i j}\end{array}\end{array}$} & \multicolumn{2}{|c|}{$\begin{array}{l}\text { Geograph. } \\
\text { Spill. } \\
\text { Column } 5 \\
v_{\mathrm{ij}}=g_{i j}\end{array}$} & \multicolumn{2}{|c|}{$\begin{array}{c}\text { Asymmetric } \\
\text { Technol. And } \\
\text { Geograph. } \\
\text { Spill. } \\
\text { Column } 6 \\
v_{\mathrm{ij}}=\boldsymbol{v}_{i j}\end{array}$} & \multicolumn{2}{|c|}{$\begin{array}{c}\text { Asymmetric } \\
\text { Technol. } \\
\text { Spill. } \\
\text { Column } 7 \\
v_{\mathrm{ij}}=\widetilde{\omega}_{i j}\end{array}$} & \multicolumn{2}{|c|}{$\begin{array}{c}\text { Geograph. } \\
\text { Spill. } \\
\text { Column } 8 \\
v_{\mathrm{ij}}=g_{i j}\end{array}$} & \multicolumn{2}{|c|}{$\begin{array}{c}\text { Asymmetric } \\
\text { Technol. And } \\
\text { Geograph. } \\
\text { Spill. } \\
\text { Column } 9 \\
v_{\mathrm{ij}}=v_{i j}\end{array}$} \\
\hline & $\begin{array}{l}0.6302 \\
(.00096)\end{array}$ & $* * *$ & $\begin{array}{l}0.6090 \\
(.00075)\end{array}$ & $* * *$ & $\begin{array}{l}0.6202 \\
(.00078)\end{array}$ & $* * *$ & $\begin{array}{l}0.6380 \\
(.00096)\end{array}$ & $* * *$ & $\begin{array}{l}0.6207 \\
(.00073)\end{array}$ & $* * *$ & $\begin{array}{l}0.6330 \\
(.00076)\end{array}$ & $* * *$ & $\begin{array}{l}0.6452 \\
(.00132)\end{array}$ & $* * *$ & $\begin{array}{l}0.5774 \\
(.00099)\end{array}$ & $* * *$ & $\begin{array}{l}0.6135 \\
(.00105)\end{array}$ & $* * *$ \\
\hline $\mathbf{K}$ & $\begin{array}{l}0.2242 \\
(.00043)\end{array}$ & $* * *$ & $\begin{array}{l}0.1838 \\
(.00035)\end{array}$ & $* * *$ & $\begin{array}{l}0.1930 \\
(.00036)\end{array}$ & $* * *$ & $\begin{array}{l}0.2122 \\
(.00041)\end{array}$ & $* * *$ & $\begin{array}{l}0.1728 \\
(.00033)\end{array}$ & $* * *$ & $\begin{array}{l}0.1814 \\
(.00035)\end{array}$ & $* * *$ & $\begin{array}{l}0.2606 \\
(.00056)\end{array}$ & $* * *$ & $\begin{array}{l}0.2323 \\
(.0005)\end{array}$ & $* * *$ & $\begin{array}{l}0.2366 \\
(.00049)\end{array}$ & $* * *$ \\
\hline CT & $\begin{array}{l}0.1749 \\
(.00033)\end{array}$ & $* * *$ & $\begin{array}{l}0.1439 \\
(.00028)\end{array}$ & $* * *$ & $\begin{array}{l}.0 .1492 \\
(.00028)\end{array}$ & $* * *$ & $\begin{array}{l}0.1735 \\
(.00033)\end{array}$ & $* * *$ & $\begin{array}{l}.0 .1427 \\
(.00027)\end{array}$ & $* * *$ & $\begin{array}{l}0.1485 \\
(.00027)\end{array}$ & $* * *$ & $\begin{array}{l}0.1698 \\
(.00039)\end{array}$ & $* * *$ & $\begin{array}{l}0.1234 \\
(.00033)\end{array}$ & $* * *$ & $\begin{array}{l}0.1293 \\
(.00033)\end{array}$ & $* * *$ \\
\hline SPILL & $\begin{array}{l}0.0766 \\
(.00188)\end{array}$ & $* * *$ & $\begin{array}{l}0.3200 \\
(.00193)\end{array}$ & $* * *$ & $\begin{array}{l}0.2842 \\
(.00195)\end{array}$ & $* * *$ & $\begin{array}{l}0.0299 \\
(.00181)\end{array}$ & $* * *$ & $\begin{array}{l}0.2773 \\
(.00185)\end{array}$ & $* * *$ & $\begin{array}{l}0.2360 \\
(.00187)\end{array}$ & $* * *$ & $\begin{array}{l}0.1351 \\
(.00217)\end{array}$ & $* * *$ & $\begin{array}{l}0.3457 \\
(.00237)\end{array}$ & $* * *$ & $\begin{array}{l}0.3455 \\
(.00246)\end{array}$ & $* * *$ \\
\hline Returns to scale & $\begin{array}{l}1.120 \\
(.00208)\end{array}$ & $* * *$ & $\begin{array}{l}1.274 \\
(.00182)\end{array}$ & $* * *$ & $\begin{array}{l}1.261 \\
(.00188)\end{array}$ & $* * *$ & $\begin{array}{l}1.108 \\
(.00206)\end{array}$ & $* * *$ & $\begin{array}{l}1.275 \\
(.00177)\end{array}$ & $* * *$ & $\begin{array}{l}1.259 \\
(.00184)\end{array}$ & $* * *$ & $\begin{array}{l}1.193 \\
(.00306)\end{array}$ & $* * *$ & $\begin{array}{l}1.235 \\
(.00226)\end{array}$ & $* * *$ & $\begin{array}{l}1.287 \\
(.00256)\end{array}$ & $* * *$ \\
\hline Number of obs. & 419 & & 419 & & 419 & & 349 & & 349 & & 349 & & 252 & & 252 & & 252 & \\
\hline $\begin{array}{l}\text { MC-ELROY R- } \\
\text { squared }\end{array}$ & 0.54 & & 0.52 & & 0.52 & & 0.57 & & 0.55 & & 0.55 & & 0.44 & & 0.44 & & 0.43 & \\
\hline t-test $H_{0}: \theta=1$ & 57.65 & $* * *$ & 150.33 & $* * *$ & 138.76 & $* * *$ & 52.08 & $* * *$ & 154.76 & $* * *$ & 140.86 & $* * *$ & 63.07 & $* * *$ & 103.83 & $* * *$ & 112.25 & $* * *$ \\
\hline F-test $H_{0}: \beta, \gamma, \delta=0$ & 38.60 & $* * *$ & 47.46 & $* * *$ & 45.93 & $* * *$ & 31.42 & $* * *$ & 39.76 & $* * *$ & 38.29 & $* * *$ & 84.64 & $* * *$ & 121.16 & $* * *$ & 111.19 & $* * *$ \\
\hline $\begin{array}{l}\text { Hansen J-test } \\
\text { p-value } \\
\text { BG-test }[\mathrm{AR}(1)] \\
\text { BG-test }[\mathrm{AR}(2)]\end{array}$ & $\begin{array}{l}17.8 \\
0.001 \\
0.27 \\
1.67\end{array}$ & & $\begin{array}{l}14.1 \\
0.007 \\
0.09 \\
0.56\end{array}$ & & $\begin{array}{l}11.3 \\
0.023 \\
0.13 \\
0.70\end{array}$ & & $\begin{array}{l}10.71 \\
0.013 \\
0.12 \\
1.47\end{array}$ & & $\begin{array}{l}6.21 \\
0.102 \\
0.03 \\
0.77\end{array}$ & & $\begin{array}{l}5.67 \\
0.129 \\
0.05 \\
1.06\end{array}$ & & $\begin{array}{l}5.04 \\
0.169 \\
0.08 \\
0.27\end{array}$ & & $\begin{array}{l}3.87 \\
0.276 \\
0.04 \\
0.16\end{array}$ & & $\begin{array}{l}4.14 \\
0.247 \\
0.05 \\
0.20\end{array}$ & \\
\hline
\end{tabular}

Notes: Standard errors reported in brackets. $(* * *)$ denotes statistical significance at the $1 \%$ level.

The instrumental variables are the one-year lagged values of the endogenous regressors (labour, physical and technological capital, and their squared value), fitted probabilities obtained from the probit estimates in the first step, one-year lagged growth rate of human capital, and the growth rate of ICT investments. § In these estimations the growth rate of labour cost is also considered as instrumental variable. 
Table 4 Technical and Morishima elasticity of substitution by size (as a mean average of the sample) over the period 1998-2003.*

\begin{tabular}{|c|c|c|c|c|c|c|c|c|c|c|c|c|c|c|c|c|}
\hline & & $\begin{array}{l}\text { Tecl } \\
\text { subs }\end{array}$ & $\begin{array}{l}\text { nical ela } \\
\text { titution }\end{array}$ & & & & & & & & Morishir & elast & city of su & stitut & ion & \\
\hline & ITALY & & $\begin{array}{l}\text { NORTH } \\
\text { WEST }\end{array}$ & & $\begin{array}{l}\text { NORTH } \\
\text { EAST }\end{array}$ & & $\begin{array}{l}\text { CENTRE- } \\
\text { SOUTH }\end{array}$ & & ITALY & & $\begin{array}{l}\text { NORTH } \\
\text { WEST }\end{array}$ & & $\begin{array}{l}\text { NORTH } \\
\text { EAST }\end{array}$ & & $\begin{array}{l}\text { CENTRE } \\
\text { SOUTH }\end{array}$ & \\
\hline L \& K & $\begin{array}{l}0.320 \\
(.0004) \\
-(1843.7538)\end{array}$ & $* * *$ & $\begin{array}{l}0.311 \\
(.0006) \\
-(1183.31)\end{array}$ & $* * *$ & $\begin{array}{l}0.287 \\
(.0006) \\
-(1271.56)\end{array}$ & $* * *$ & $\begin{array}{l}0.386 \\
(.0006) \\
-(961.0528)\end{array}$ & $* * *$ & $\begin{array}{l}0.325 \\
(.0033) \\
-(203.125)\end{array}$ & $* * *$ & $\begin{array}{l}0.438 \\
(.0048) \\
-(116.1643)\end{array}$ & $* * *$ & $\begin{array}{l}0.200 \\
(.0065) \\
-(122.22)\end{array}$ & $* * *$ & $\begin{array}{l}0.309 \\
(.0051) \\
-(134.7801)\end{array}$ & $* * *$ \\
\hline K \& L & $\begin{array}{l}3.125 \\
(.0036)\end{array}$ & $* * *$ & $\begin{array}{l}3.214 \\
(.006) \\
(368.23)\end{array}$ & $* * *$ & $\begin{array}{l}3.490 \\
(.0068) \\
(364.39)\end{array}$ & $* * *$ & $\begin{array}{l}2.593 \\
(.0043) \\
(370.6776)\end{array}$ & $* * *$ & $\begin{array}{l}0.431 \\
(.0028) \\
-(199782)\end{array}$ & $* * *$ & $\begin{array}{l}0.559 \\
(.0043) \\
-(101.7778)\end{array}$ & $* * *$ & $\begin{array}{l}0.340 \\
(.0057) \\
-(116.1)\end{array}$ & $* * *$ & $\begin{array}{l}0.316 \\
(.0042) \\
-(161.9365)\end{array}$ & $* * *$ \\
\hline $\mathbf{L} \& \mathbf{C T}$ & $\begin{array}{l}0.228 \\
(.0002) \\
-(3570.038)\end{array}$ & $* * *$ & $\begin{array}{l}0.241 \\
(.0004) \\
-(1932.07)\end{array}$ & $* * *$ & $\begin{array}{l}0.235 \\
(.0004) \\
-(2104.47)\end{array}$ & $* * *$ & $\begin{array}{l}0.211 \\
(.00039) \\
-(2003.0592)\end{array}$ & $* * *$ & $\begin{array}{l}0.127 \\
(.0075) \\
-(116.312)\end{array}$ & $* * *$ & $\begin{array}{l}0.118 \\
(.0104) \\
-(84.9204)\end{array}$ & $* * *$ & $\begin{array}{l}0.223 \\
(.0161) \\
-(48.35)\end{array}$ & $* * *$ & $\begin{array}{l}-0.494 \\
(.0183) \\
-(81.7933)\end{array}$ & $* * *$ \\
\hline CT \& L & $\begin{array}{l}4.379 \\
(.0041) \\
(815.3469)\end{array}$ & $* * *$ & $\begin{array}{l}4.157 \\
(.0068) \\
(464.8)\end{array}$ & $* * *$ & $\begin{array}{l}4.264 \\
(.0066) \\
(493.58)\end{array}$ & $* * *$ & $\begin{array}{l}4.743 \\
(.00886) \\
(422.3084)\end{array}$ & $* * *$ & $\begin{array}{l}0.557 \\
(.0082) \\
-(54.3024)\end{array}$ & $* * *$ & $\begin{array}{l}0.540 \\
(.0109) \\
-(42.2481)\end{array}$ & $* * *$ & $\begin{array}{l}0.711 \\
(.0168) \\
-(17.23)\end{array}$ & $* * *$ & $\begin{array}{l}-0.309 \\
(.0183) \\
-(71.5989)\end{array}$ & $* * *$ \\
\hline K \& CT & $\begin{array}{l}0.714 \\
(.0012) \\
-(243.643)\end{array}$ & $* * *$ & $\begin{array}{l}0.773 \\
(.0021) \\
-(109.84)\end{array}$ & $* * *$ & $\begin{array}{l}0.818 \\
(.0022) \\
-(81.24)\end{array}$ & $* * *$ & $\begin{array}{l}0.547 \\
(.00161) \\
-(281.1149)\end{array}$ & $* * *$ & $\begin{array}{l}0.018 \\
(.0083) \\
-(118.366)\end{array}$ & $* *$ & $\begin{array}{l}-0.006 \\
(.0116) \\
-(86.3891)\end{array}$ & & $\begin{array}{l}0.080 \\
(.0178) \\
-(51.75)\end{array}$ & $* * *$ & $\begin{array}{l}-0.503 \\
(.0198) \\
-(75.8875)\end{array}$ & $* * *$ \\
\hline CT \& K & $\begin{array}{l}1.401 \\
(0.002) \\
(173.902)\end{array}$ & $* * *$ & $\begin{array}{l}1.294 \\
(.0035) \\
(84.92)\end{array}$ & $* * *$ & $\begin{array}{l}1.222 \\
(.0033) \\
(66.49)\end{array}$ & $* * *$ & $\begin{array}{l}1.829 \\
(.0054) \\
(153.6635)\end{array}$ & $* * *$ & $\begin{array}{l}-0.123 \\
(.010) \\
-(116.209)\end{array}$ & $* * *$ & $\begin{array}{l}0.002 \\
(.0126) \\
-(78.9976)\end{array}$ & & $\begin{array}{l}-0.310 \\
(.019) \\
-(68.84)\end{array}$ & $* * *$ & $\begin{array}{l}0.102 \\
(.0234) \\
-(38.3815)\end{array}$ & $* * *$ \\
\hline L \& Sp & $\begin{array}{l}0.460 \\
(.002) \\
-(275.261)\end{array}$ & $* * *$ & $\begin{array}{l}0.458 \\
(.0031) \\
-(173.45)\end{array}$ & $* * *$ & $\begin{array}{l}0.373 \\
(.0029) \\
-(213.4)\end{array}$ & $* * *$ & $\begin{array}{l}0.563 \\
(.00401) \\
-(109.0585)\end{array}$ & $* * *$ & $\begin{array}{l}0.919 \\
(.0004) \\
-(194.499)\end{array}$ & $* * *$ & $\begin{array}{l}0.942 \\
(.0006) \\
-(97.4616)\end{array}$ & $* * *$ & $\begin{array}{l}0.919 \\
(.0007) \\
-(114.65)\end{array}$ & $* * *$ & $\begin{array}{l}0.880 \\
(.0008) \\
-(154.1762)\end{array}$ & $* * *$ \\
\hline Sp \& L & $\begin{array}{l}2.176 \\
(.009) \\
(126.4923)\end{array}$ & $* * *$ & $\begin{array}{l}2.182 \\
(.0149) \\
(79.47)\end{array}$ & $* * *$ & $\begin{array}{l}2.682 \\
(.0211) \\
(79.57)\end{array}$ & $* * *$ & $\begin{array}{l}1.776 \\
(.01263) \\
(61.4115)\end{array}$ & $* * *$ & $\begin{array}{l}0.907 \\
(.0005) \\
-(179.952)\end{array}$ & $* * *$ & $\begin{array}{l}0.924 \\
(.0008) \\
-(96.2585)\end{array}$ & $* * *$ & $\begin{array}{l}0.914 \\
(.000919) \\
-(94.02)\end{array}$ & $* * *$ & $\begin{array}{l}0.845 \\
(.001) \\
-(161.0287)\end{array}$ & $* * *$ \\
\hline$K \& S p$ & $\begin{array}{l}1.436 \\
(.006) \\
(73.1462)\end{array}$ & $* * *$ & $\begin{array}{l}1.472 \\
(.0098) \\
(48.32)\end{array}$ & $* * *$ & $\begin{array}{l}1.301 \\
(.01) \\
(30.19)\end{array}$ & $* * *$ & $\begin{array}{l}1.460 \\
(.01008) \\
(45.6381)\end{array}$ & $* * *$ & $\begin{array}{l}1.005 \\
(.00002) \\
(206.1724)\end{array}$ & $* * *$ & $\begin{array}{l}1.005 \\
(.00004) \\
(133.3735)\end{array}$ & $* * *$ & $\begin{array}{l}1.006 \\
(.00005) \\
(119.74)\end{array}$ & $* * *$ & $\begin{array}{l}1.005 \\
(.00004) \\
(116.9103)\end{array}$ & $* * *$ \\
\hline Sp \& K & $\begin{array}{l}0.696 \\
(0.003) \\
-(105.0488)\end{array}$ & $* * *$ & $\begin{array}{l}0.679 \\
(.0045) \\
-(71.14)\end{array}$ & $* * *$ & $\begin{array}{l}0.769 \\
(.0059) \\
-(39.28)\end{array}$ & $* * *$ & $\begin{array}{l}0.685 \\
(.00473) \\
-(66.6298)\end{array}$ & $* * *$ & $\begin{array}{l}0.407 \\
(.00298) \\
-(199.064)\end{array}$ & $* * *$ & $\begin{array}{l}0.498 \\
(.0044) \\
-(115.2219)\end{array}$ & $* * *$ & $\begin{array}{l}0.282 \\
(.005982) \\
-(119.99)\end{array}$ & $* * *$ & $\begin{array}{l}0.430 \\
(.0045) \\
-(126.7733)\end{array}$ & $* * *$ \\
\hline $\mathbf{C T} \& \mathbf{S p}$ & $\begin{array}{l}2.012 \\
(.0095) \\
(106.0851)\end{array}$ & $* * *$ & $\begin{array}{l}1.905 \\
(.0146) \\
(62.16)\end{array}$ & $* * *$ & $\begin{array}{l}1.590 \\
(.0137) \\
(43.08)\end{array}$ & $* * *$ & $\begin{array}{l}2.671 \\
(.02173) \\
(76.8859)\end{array}$ & $* * *$ & $\begin{array}{l}1.021 \\
(.0001) \\
(258.2686)\end{array}$ & $* * *$ & $\begin{array}{l}1.017 \\
(.0001) \\
(158.144)\end{array}$ & $* * *$ & $\begin{array}{l}1.026 \\
(.0002) \\
(162.2)\end{array}$ & $* * *$ & $\begin{array}{l}1.026 \\
(.0002) \\
(126.1664)\end{array}$ & $* * *$ \\
\hline Sp \& CT & $\begin{array}{l}0.497 \\
(.0024)\end{array}$ & $* * *$ & $\begin{array}{l}0.525 \\
(.004)\end{array}$ & $* * *$ & $\begin{array}{l}0.629 \\
(.0054)\end{array}$ & $* * *$ & $\begin{array}{l}0.374 \\
(.00305)\end{array}$ & $* * *$ & $\begin{array}{l}0.141 \\
(.0073)\end{array}$ & $* * *$ & $\begin{array}{l}0.137 \\
(.0101)\end{array}$ & $* * *$ & $\begin{array}{l}0.231 \\
(.0157)\end{array}$ & $* * *$ & $\begin{array}{l}-0.457 \\
(.0181)\end{array}$ & $* * *$ \\
\hline$\S$ & -(213.4538) & & -(118.4) & & $-(68.48)$ & & $-(205.3531)$ & & $-(116.924)$ & & $-(85.4255)$ & & -(48.89) & & $-(80.7103)$ & \\
\hline
\end{tabular}

Note: Standard errors reported in brackets. $\left({ }^{*}\right),\left({ }^{* *}\right),\left({ }^{* * *}\right)$ denote statistical significance at the $10 \%, 5 \%$ and $1 \%$ level, respectively.

$\S:$ t-test $H_{0}: \sigma_{i j}=1$

${ }^{*}$ Data refers to the results obtained using eq. 5 as weighting system of R\&D spillovers 


\section{Appendix}

Table A.1 Results on the probability of investing in R\&D for Italian manufacturing firms. Probit estimates over the period 1998-2003.

\begin{tabular}{|c|c|c|c|c|c|c|c|c|c|}
\hline \multirow[b]{2}{*}{$\ln (\mathrm{H})$} & \multicolumn{3}{|c|}{$\begin{array}{c}\text { Asymmetric Technol. } \\
\text { Spill. }\end{array}$} & \multicolumn{3}{|c|}{ Geograph. Spill. } & \multicolumn{3}{|c|}{$\begin{array}{l}\text { Asymmetric Technol. } \\
\text { And Geograph. Spill. }\end{array}$} \\
\hline & 0.020 & $(.003)$ & $* * *$ & 0.022 & $(.003)$ & $* * *$ & 0.020 & $(.003)$ & $* * *$ \\
\hline $\ln (\mathrm{cf})$ & 0.050 & $(.027)$ & * & 0.069 & $(.026)$ & $* * *$ & 0.069 & $(.026)$ & $* * *$ \\
\hline D_exp & 0.523 & $(.061)$ & $* * *$ & 0.572 & $(.059)$ & $* * *$ & 0.580 & $(.059)$ & $* * *$ \\
\hline $\ln (\mathrm{ict})$ & 0.207 & $(.023)$ & $* * *$ & 0.168 & $(.021)$ & $* * *$ & 0.167 & $(.022)$ & $* * *$ \\
\hline North-West & 0.188 & $(.06)$ & $* * *$ & 0.183 & (.058) & $* * *$ & 0.267 & $(.059)$ & $* * *$ \\
\hline North-East & 0.240 & $(.075)$ & $* * *$ & 0.271 & $(.088)$ & $* * *$ & 0.628 & $(.086)$ & $* * *$ \\
\hline Centre & -0.128 & $(.097)$ & & 0.291 & $(.183)$ & & 1.345 & (.169) & $* * *$ \\
\hline D_DB & 0.073 & $(.12)$ & & 0.090 & $(.116)$ & & 0.003 & $(.117)$ & \\
\hline D_DC & 0.322 & (.155) & $* *$ & 0.237 & $(.146)$ & & 0.227 & $(.148)$ & \\
\hline D_DD & 0.080 & $(.157)$ & & -0.012 & $(.15)$ & & 0.051 & (.151) & \\
\hline D_DE & -0.395 & $(.164)$ & $* *$ & -0.392 & $(.152)$ & $* *$ & -0.431 & (.153) & $\star \star \star \star$ \\
\hline D_DF & 0.118 & $(.441)$ & & 0.336 & $(.333)$ & & -0.045 & $(.368)$ & \\
\hline D_DG & 0.538 & $(.148)$ & $* * *$ & 0.523 & (.138) & $* * *$ & 0.486 & $(.142)$ & $* * *$ \\
\hline D_DH & 0.152 & $(.135)$ & & 0.280 & (.13) & $* *$ & 0.197 & $(.132)$ & \\
\hline D_DI & -0.046 & $(.131)$ & & 0.009 & $(.127)$ & & -0.032 & (.131) & \\
\hline D_DJ & -0.212 & $(.115)$ & * & -0.155 & (.108) & & -0.207 & $(.108)$ & * \\
\hline D_DK & 0.368 & $(.117)$ & $* * *$ & 0.422 & $(.111)$ & $* * *$ & 0.389 & (.111) & $* * *$ \\
\hline D_DL & 0.544 & $(.131)$ & $* * *$ & 0.606 & (.124) & $* * *$ & 0.623 & $(.126)$ & $* * *$ \\
\hline D_DM & -0.061 & $(.172)$ & & -0.008 & (.172) & & 0.082 & (.179) & \\
\hline D_DN & 0.034 & (.137) & & 0.041 & $(.129)$ & & -0.025 & (.129) & \\
\hline $\ln (\mathrm{k})$ & 0.426 & $(.871)$ & & -0.841 & $(.671)$ & & -1.356 & $(.938)$ & \\
\hline $\ln (1)$ & 8.821 & (3.181) & $* * *$ & 0.560 & $(1.233)$ & & 1.798 & (1.584) & \\
\hline $\ln (\mathrm{sp})$ & 4.721 & (3.02) & & -2.355 & (2.156) & & -23.741 & (3.368) & $\star \star \star *$ \\
\hline $\ln (1) \ln (\mathrm{k})$ & -0.056 & $(.061)$ & & -0.023 & $(.03)$ & & -0.024 & $(.032)$ & \\
\hline $\ln (1) \ln (\mathrm{sp})$ & -0.451 & $(.212)$ & $* *$ & 0.005 & $(.093)$ & & -0.021 & $(.122)$ & \\
\hline $\ln (\mathrm{k}) \ln (\mathrm{sp})$ & -0.016 & $(.057)$ & & 0.075 & $(.05)$ & & 0.119 & $(.071)$ & * \\
\hline$[\ln (1)]^{2}$ & -0.738 & $(.261)$ & $* * *$ & -0.095 & $(.067)$ & & -0.251 & $(.073)$ & $* * *$ \\
\hline$[\ln (\mathrm{k})]^{2}$ & 0.013 & $(.019)$ & & 0.005 & $(.019)$ & & 0.007 & $(.019)$ & \\
\hline$[\ln (s p)]^{2}$ & -0.217 & $(.205)$ & & 0.160 & $(.179)$ & & 2.008 & $(.263)$ & $* * *$ \\
\hline $\mathrm{t}$ & -5.307 & $(1.068)$ & $* * *$ & 0.065 & $(.593)$ & & 0.791 & $(.74)$ & \\
\hline$t \ln (1)$ & 0.267 & $(.07)$ & $* * *$ & 0.026 & $(.025)$ & & 0.029 & $(.027)$ & \\
\hline $\mathrm{t} \ln (\mathrm{k})$ & -0.016 & $(.016)$ & & -0.030 & $(.015)$ & $* *$ & -0.032 & $(.016)$ & $* *$ \\
\hline$t \ln (s p)$ & 0.264 & $(.068)$ & $* * *$ & 0.011 & $(.045)$ & & -0.083 & $(.057)$ & \\
\hline$(t)^{2}$ & 0.343 & $(.04)$ & $* * *$ & -0.015 & $(.029)$ & & 0.080 & $(.031)$ & $* *$ \\
\hline constant & -49.503 & $(22.63)$ & $* *$ & 11.214 & (13.38) & & 132.142 & $(22.02)$ & $* * *$ \\
\hline Obs. No. & 3595 & & & 3595 & & & 3595 & & \\
\hline Wald test & 930.92 & & & 817.89 & & & 837.71 & & \\
\hline $\begin{array}{l}\text { p-value } \\
\text { Pseudo }\end{array}$ & 0.000 & & & 0.000 & & & 0.000 & & \\
\hline $\mathrm{R}^{\wedge} 2$ & 0.282 & & & 0.221 & & & 0.244 & & \\
\hline
\end{tabular}

Notes: Standard errors in brackets. $(* * *),(* *),(*)$ denote statistical significance at $1 \%, 5 \%$ and $10 \%$, respectively. Legend: H: human capital; cf: cash flow; D_exp: dummy equal to one if the firms exports; ict: ICT investments; k: physical capital; 1: labour; sp: spillovers; sectoral (according to the Ateco91 classification: $\mathrm{DA}=$ Food, Beverages \& Tobacco, $\mathrm{DB}=$ Textiles \& Apparel, $\mathrm{DC}=$ Leather, $\mathrm{DD}=$ Wood Products, $\mathrm{DE}=$ Paper, Paper Prod. \& Printing, DF=Petroleum Refineries \& Product, $D G=$ Chemicals, $D H=$ Rubber \& Plastic Products, DI=Non-Metallic Mineral Products, DJ=Basic Metal \& Fab. Met. Prod., DK=Non-Electrical Machinery, $\mathrm{DL}=$ Electrical Machinery and Electronics, $\mathrm{DM}=$ Motor vehicles \& Other Transport Equipment, $\mathrm{DN}=\mathrm{Other}$ Manufacturing Industries) and territorial (North-West, North-East, Centre and South) dummies (the control groups are traditional industries and Southern firms, respectively). 


\section{A.2 Estimation of translog coefficients}

Under the assumption of homogeneity of grade $\theta$, the constraints $\sum_{i} \alpha_{i}=1, \sum_{j} \beta_{i j}=0$ and $\sum_{i} \gamma_{i T}=0$ are imposed.

Thus, the system of equations becomes:

$$
\begin{aligned}
& \ln Y_{i t}=\theta\left(\alpha+\alpha_{L} \ln L_{i t}+\alpha_{K} \ln K_{i t}+\alpha_{C t} \ln C T_{i t}+\left(1-\alpha_{L}-\alpha_{K}-\alpha_{C t}\right) \ln S p i l l_{i t}+\xi_{T} \cdot t\right. \\
& +\frac{1}{2}\left(-\beta_{L K}-\beta_{L C t}-\beta_{L S p}\right)\left(\ln L_{i t}\right)^{2}+\frac{1}{2}\left(-\beta_{L K}-\beta_{K C t}-\beta_{K S p}\right)\left(\ln K_{i t}\right)^{2} \\
& +\frac{1}{2}\left(-\beta_{L C t}-\beta_{K C t}-\beta_{C t S p}\right)\left(\ln C T_{i t}\right)^{2}+\frac{1}{2}\left(-\beta_{L S p}-\beta_{K S p}-\beta_{C t S p}\right)\left(\ln S p i l l_{i t}\right)^{2}+\frac{1}{2} \delta_{T T}(t)^{2} \\
& +\beta_{L K} \ln L_{i t} \ln K_{i t}+\beta_{L C t} \ln L_{i t} \ln C T_{i t}+\beta_{L S p} \ln L_{i t} \ln S p i l l_{i t} \\
& +\beta_{K C t} \ln K_{i t} \ln C T_{i t}+\beta_{K S p} \ln K_{i t} \ln S p i l l_{i t}+\beta_{C t S p} \ln C T_{i t} \ln S p i l l_{i t} \\
& \left.+\gamma_{L T} \ln L_{i t} \cdot t+\gamma_{K T} \ln K_{i t} \cdot t+\gamma_{C t T} \ln C T_{i t} \cdot t+\left(-\gamma_{L T}-\gamma_{K T}-\gamma_{C t T}\right) \ln S p i l l_{i t} \cdot t\right) \\
& +\eta_{\mathrm{s}} d p_{s}+\eta_{g} d a_{g}+\varepsilon_{i t} \\
& S_{L, i t}=\alpha_{L}+\left(-\beta_{L C t}-\beta_{K C t}-\beta_{C t S p}\right) \ln L_{i t}+\beta_{L K} \ln K_{i t}+\beta_{L C t} \ln C T_{i t}+\beta_{L S p} \ln S_{\text {Spill }} \\
& +\gamma_{L T} \cdot t+u_{L, i t} \\
& S_{K, i t}=\alpha_{K}+\beta_{L K} \ln L_{i t}+\left(-\beta_{L K}-\beta_{K C t}-\beta_{K S p}\right) \ln K_{i t}+\beta_{K C t} \ln C T_{i t}+\beta_{K S p} \ln \text { Spill }_{i t} \\
& +\gamma_{K T} \cdot t+u_{K, i t} \\
& S_{C t, i t}=\alpha_{C t}+\beta_{L C t} \ln L_{i t}+\beta_{K C t} \ln K_{i t}+\left(-\beta_{L C t}-\beta_{K C t}-\beta_{C t S p}\right) \ln C T_{i t}+\beta_{C t S p} \ln S_{p i l l} \\
& +\gamma_{C t T} \cdot t+u_{C t, i t}
\end{aligned}
$$


Table A.2 Estimated coefficients of the translog production function. Italian manufacturing firms, 1998-2003. Estimation Method: nonlinear 3SLS.

\begin{tabular}{|c|c|c|c|c|c|c|c|c|c|}
\hline & \multicolumn{3}{|c|}{$\begin{array}{l}\text { Asymmetric } \\
\text { Technol. Spill. } \\
\text { Column } 1 \\
\mathrm{v}_{\mathrm{ij}}=\widetilde{\omega}_{i j}\end{array}$} & \multicolumn{2}{|c|}{$\begin{array}{l}\text { Geograph. Spill. } \\
\qquad \begin{array}{c}\text { Column } 2 \\
\mathrm{U}_{\mathrm{ij}}=\mathrm{g}_{\mathrm{ij}}\end{array}\end{array}$} & \multicolumn{4}{|c|}{$\begin{array}{c}\text { Asymmetric } \\
\text { Technol. And } \\
\text { Geograph. Spill. } \\
\text { Column } 3 \\
\mathrm{U}_{\mathrm{ij}}=v_{i j}\end{array}$} \\
\hline$\alpha$ & 1.6416 & $(0.011)$ & $* * *$ & 1.8178 & $(0.008)$ & $* * *$ & 1.6419 & $(0.008)$ & $* * *$ \\
\hline$\alpha_{L}$ & 0.6876 & $(0.000)$ & $* * *$ & 0.7422 & $(0.000)$ & $* * *$ & 0.7374 & $(0.000)$ & *** \\
\hline$\alpha_{K}$ & 0.1640 & $(0.001)$ & $* * *$ & 0.1686 & $(0.001)$ & $* * *$ & 0.1675 & $(0.001)$ & $* * *$ \\
\hline$\alpha_{C t}$ & 0.1803 & $(0.000)$ & $* \star *$ & 0.1884 & $(0.000)$ & $* * *$ & 0.1844 & $(0.000)$ & $* * *$ \\
\hline$\beta_{\mathrm{LK}}$ & -0.0164 & $(0.000)$ & $* * *$ & -0.0153 & $(0.000)$ & $* * *$ & -0.0155 & $(0.000)$ & $* * *$ \\
\hline$\beta_{\mathrm{LCt}}$ & -0.0031 & $(0.000)$ & $* * *$ & -0.0026 & $(0.000)$ & $* * *$ & -0.0026 & $(0.000)$ & *** \\
\hline$\beta_{\mathrm{LSp}}$ & 0.0004 & $(0.000)$ & $* * *$ & 0.0004 & $(0.000)$ & $* * *$ & 0.0004 & $(0.000)$ & $* * *$ \\
\hline$\beta_{K C t}$ & -0.0045 & $(0.000)$ & $* * *$ & -0.0039 & $(0.000)$ & $* * *$ & -0.0040 & $(0.000)$ & $* * *$ \\
\hline$\beta_{K S p}$ & 0.0002 & $(0.000)$ & $* * *$ & 0.0002 & $(0.000)$ & $* * *$ & 0.0002 & $(0.000)$ & $* * *$ \\
\hline$\beta_{\mathrm{CtSp}}$ & 0.0002 & $(0.000)$ & $* * *$ & 0.0002 & $(0.000)$ & $* * *$ & 0.0002 & $(0.000)$ & $* * *$ \\
\hline$\xi_{T}$ & -0.0350 & $(0.004)$ & $* * *$ & -0.6152 & $(0.004)$ & $* * *$ & -0.5176 & $(0.004)$ & $* * *$ \\
\hline YLT & -0.0176 & $(0.000)$ & $* * *$ & -0.0572 & $(0.000)$ & $* * *$ & -0.0516 & $(0.000)$ & *** \\
\hline $\mathrm{Y}_{\mathrm{TK}}$ & -0.0063 & $(0.000)$ & $* * *$ & -0.0208 & $(0.000)$ & $* * *$ & -0.0187 & $(0.000)$ & $* * *$ \\
\hline YTCt & -0.0079 & $(0.000)$ & $* * *$ & -0.0210 & $(0.000)$ & $* * *$ & -0.0188 & $(0.000)$ & $* * *$ \\
\hline$\delta_{\mathrm{TT}}$ & -0.0359 & $(0.001)$ & $* * *$ & -0.0500 & $(0.001)$ & $* \star *$ & -0.0420 & $(0.001)$ & $* * *$ \\
\hline$\theta$ & 1.1326 & $(0.001)$ & $* * *$ & 1.2780 & $(0.001)$ & $* * *$ & 1.2745 & $(0.001)$ & $* * *$ \\
\hline dp2 & 0.1309 & $(0.003)$ & $* * *$ & 0.1530 & $(0.002)$ & $* * *$ & 0.1404 & $(0.003)$ & $* * *$ \\
\hline dp3 & 0.1287 & $(0.002)$ & $* * *$ & 0.1447 & $(0.002)$ & $* * *$ & 0.1429 & $(0.002)$ & *** \\
\hline dp4 & 0.0478 & $(0.004)$ & $* * *$ & 0.0963 & $(0.003)$ & $* \star *$ & 0.0828 & $(0.003)$ & $* * *$ \\
\hline da1 & 0.1025 & $(0.004)$ & $* * *$ & -0.3391 & $(0.003)$ & $* * *$ & -0.1918 & $(0.003)$ & $* * *$ \\
\hline da2 & 0.1564 & $(0.004)$ & $* * *$ & -0.2744 & $(0.003)$ & $* * *$ & -0.1264 & $(0.003)$ & $* * *$ \\
\hline da3 & 0.0890 & $(0.004)$ & $* * *$ & -0.2764 & $(0.004)$ & $* * *$ & -0.1427 & $(0.004)$ & *** \\
\hline
\end{tabular}

Notes: Standard errors reported in brackets. $(* * *)$ denotes statistical significance at the $1 \%$ level. The instrumental variables are the one-year lagged values of the endogenous regressors (labour, physical and technological capital, and their squared value), fitted probabilities obtained from the probit estimates in the first step, one-year lagged growth rate of human capital, and the growth rate of ICT investments. 


\section{References}

Adams, J.D., Jaffe, A.B., 1996. Bounding the effect of R\&D: an investigation using matched establishment-firm data. RAND J. Econ. 27, 700-721.

Aiello, F., Cardamone, P., 2005. R\&D spillovers and productivity growth. Further evidence from Italian manufacturing microdata. Appl. Econ. Letters. 12, 625-631.

Aiello, F., Cardamone, P., 2008. R\&D Spillovers and Firms' Performance in Italy. Evidence from a Flexible Production Function. Empirical Econ. 34, 143-166.

Aiello, F., Pupo, V., 2004. Il tasso di rendimento degli investimenti in Ricerca e Sviluppo delle imprese innovatrici italiane. Rivista Politica Econ. May-June, 81-117.

Aiello, F., Cardamone, P., Pupo, V. 2005. Produttività e capitale tecnologico nel settore manifatturiero italiano. L'industria - Rivista di Economia e Politica Industriale. 2005/1, 119-145.

Aiello, F., Scoppa, V., 2000. Uneven Regional Development in Italy: Explaining Differences in Productivity Levels. Giornale Econ. 60, 270-98.

Aldieri, L., Cincera, M., 2009. Geographic and technological R\&D spillovers within the triad: Micro evidence from US patents. J. Tech. Transfer. 34, 196-211.

Antonioli, B., Fazioli, R., Filippini M., 2000. Il servizio di igiene urbana italiano tra concorrenza e monopolio. in: Cambini, C., Bulckaen, F. (Eds.), I servizi di pubblica utilità. Concorrenza e regolazione nei nuovi mercati, Franco Angeli, Milan.

Arrow, K.J., 1962. The Economic Implications of Learning by Doing. Rev. Econ. Stud. 29, 155-173.

Atzeni, G., Carboni O., 2006. Regional Disparity in ICT Adoption: an Empirical Evaluation of The Effects of Subsidies in Italy. Crenos Working Paper 2006/08, University of Cagliari and Sassari.

Audretsch, D.B., Feldmann, M.P., 2004. Knowledge Spillovers and the Geography of Innovation. Handbook of Regional and Urban Economics. 4, 2713-2739.

Banca d'Italia (2009), Mezzogiorno e Politiche regionali, Workshops and Conferences n. 2. Bank of Italy, Rome.

Becker, B., Pain, N., 2003. What determines Industrial R\&D Expenditure in the UK? National Institute of Economic and Social Research Discussion Paper n. 211.

Berndt, E.R., Christensen, L.R., 1973. The Translog Function and the Substitution of equipment, structures, and labor in U.S. manufacturing 1929-68. J. Econometrics. 1, 81114.

Bhattacharya, M., Bloch, H., 2004. Determinants of Innovation. Small Bus. Econ. 22, $155-$ 162.

Bianchi, C., Menegatti, M., 1997. Differenziali regionali di produttività e crescita economica: un riesame della convergenza in Italia nel periodo 1970-94. Stud. Econ. 3: 15-42.

Botazzi, L., Peri, G., 2003. Innovation and spillovers in regions: Evidence from European patent data. Europ. Econ. Rev. 47, 687-710.

Carmeci, G., Mauro, L., 2002. The Convergence of the Italian Regions and Unemployment. Theory and Evidence. J. Reg. Sci. 42, 509-532.

Chan, M.W.L, Mountain, D.C., 1983. Economies of scale, and the Tornqvist discrete measure of productivity. Rev. Econ. Statist. 65, 663-667.

Charnes, A., Cooper, W.W., Rhodes, E., 1978. Measuring Efficiency of Decision Making Units. European Journal of Operational Research. 2, 429-444. 
Christensen, L.R., Jorgenson, D.W., Lau, L.J., 1973. Trascendental logarithmic production frontiers. Rev. Econ. Statist. 55, 28-45.

Ciccone, A., 2004. Human capital as a Factor of Growth and Employment at the Regional Level: The Case of Italy. Unpublished.

Cincera, M., 2005. Firms' productivity growth and R\&D Spillovers: an analysis of alternative technological proximity measures. CEPR Discussion paper n. 4984.

Cohen, W.M., Levinthal, D.A., 1989. Innovation and Learning: The two Faces of R\&D. The Econ. J. 99, 569-596.

Cohen, W.M., Levinthal D.A., 1990. Absorptive Capacity: A New Perspective on Learning and Innovation. Administrative Science Quarterly. 5, 128-152.

Cosci, S., Mattesini, F., 1997. Credito e sviluppo nelle province italiane”, in : Cesarini F., Ferri G., and Giardino M. (Eds), Credito e Sviluppo. Banche locali cooperative e imprese minori, Il Mulino, Bologna.

Del Monte, A., Papagni, E., 2003. R\&D and the growth of firms: empirical analysis of a panel of Italian firms. Res. Pol. 32, 1003-1014.

Di Giacinto, V., Nuzzo, G., 2006. Explaining labour productivity differentials across Italian regions: the role of socio-economic structure and factor endowments. Pap. Reg. Sci. 85, 299 -320 .

Di Liberto, A., Pigliaru, F., Mura, R., 2008. How to Measure the Unobservable. A Panel Technique for the analysis of TFP Convergence. Oxford Econ. Pap. 60, 343-368.

Evangelista, R., Iammarino, S., Mastrostefano, V., Silvani, A., 2002. Looking for Regional System of Innovation: Evidence from the Italian Innovation Survey. Reg. Stud. 36, 173-186.

Fabiani, S., Pellegrini, G., 1997. Education, infrastructure, geography and growth: an empirical analysis of the development of Italian provinces. Temi di discussione, n. 323, Bank of Italy, Rome.

Feser, E.J., 2004. A Flexible Test for Agglomeration Economies in two U.S. Manufacturing Industries. CES Working Paper n. 14, U.S. Census Bureau.

Goel, D., 2002. Impact of Infrastructure on Productivity: Case of Indian Registered Manufacturing. CDP Working Paper n. 106, Delhi School of Economics.

Griliches, Z., 1979. Issues in Assessing the Contribution of Research and Development to Productivity Growth. Bell J. Econ. 10, 92-116.

Griliches, Z., 1991. The Search for R\&D Spillovers. Scand. J. Econ. 94, 29-47.

Gustavsson, P., Poldhal, A., 2003. Determinants of firms R\&D: Evidence from Swedish firm level data. FIEF Working Paper Series 2003 n. 190.

Hall, B.H., Mairesse, J., 1995. Exploring the Relationship between R\&S and Productivity in French Manufacturing Firms. J. Econometrics. 65, 265-293.

Harhoff, D., 1998. R\&D and Productivity in German Manufacturing Firms. Econ. Innovation New Tech. 6, 29-49.

Harhoff, D., 2000. R\&D Spillovers, technological Proximity, and productivity Growth Evidence from German Panel Data. Schmalenbach Business Review. 52, 238-260.

Inkmann, J., Pohlmeier, W., 1995. R\&D Spillovers, Technological Distance, and Innovative Success. Unpublished, University of Kostanz, 1995.

Jaffe, A.B., 1986. Technology Opportunity and Spillovers of R\&D: Evidence from firms patents, profits and market value. Amer. Econ. Rev. 76, 984-1001. 
Jaffe, A.B., 1988. Demand and Supply Influences in R\&D Intensity and Productivity Growth. The Rev. Econ. Statist. 70, 431-437.

Kaiser, U., 2002. Measuring knowledge spillovers in manufacturing and services: an empirical assessment of alternative approaches. Res. Pol. 31, 125-144.

Kim. H.Y., 1992. The Translog Production Function and Variariables Returns to Scale. Rev. Econ. Statist. 74, 546-552.

Koo, J., 2005. Technology Spillovers, Agglomeration, and Regional Economic Development. Journal of Planning Literature. 20, 99-115.

Lall, S., Shalizi, Z., Deichmann, U., 2001. Agglomeration Economies and Productivity in Indian Industry. Policy Research Working Paper n. 2663, The World Bank Development Research Group.

Leo, H., 2003. Determinants of Innovative Activities at the Firm Level. Paper presented to the International Workshop "Empirical Studies on Innovation in Europe", 1-2 December 2003, Faculty of Economics - University of Urbino, Italy.

Los, B., Verspagen, B., 2000. R\&D Spillovers and Productivity: Evidence from U.S. Manufacturing Microdata. Empirical Econ. 25, 127-48.

Maffezzoli, M., 2006. Convergence Across Italian Regions and the Role of Technological Catch-Up. B.E. Journal in Macroeconomics, Topics, 6, 1, Article 15.

Mairesse, J., Hall, B.H., 1996. Estimating the Productivity of Research and Development: An Exploration of GMM Method Using Data on French an USA Manufacturing Firms. NBER Working Paper n. 5501.

May, J.D., Denny, M., 1979. Factor Augmenting Technical Progress and Productivity in U.S. Manufacturing. Int. Econ. Rev. 20, 759-774.

Medda, G., Piga, C., 2004. R\&S e Spillovers industriali: Un'analisi sulle imprese italiane. Crenos Working Paper n. 2004/06.

Morishima, M., 1967. A Few Suggestions on the Theory of Elasticity (in Japanese). Keizai Hyoron 16, 144-150.

Orlando, M., 2000. On the importance of geographic and technological proximity for R\&D spillovers: An empirical investigation. Federal Reserve Bank of Kansas City, RWP 00-02.

Osservatorio Enea, 2006. L'Italia nella competizione tecnologica internazionale. Quinto rapporto. Sintesi e scenari generali - Osservatorio sull'Italia nella Competizione Tecnologica Internazione. 5th report, June 2006.

Paci, R., Pigliaru, F., 1995. Differenziali di crescita tra le regioni italiane: un'analisi crosssection. Rivista Politica Econ. 10, 3-34.

Paci, R., Saba, F., 1998. The empirics of regional economic growth in Italy 1951-1993. Rivista Int. Sci. Econ. Com. 45 , 515-542.

Parisi, M.L., Schiantarelli, F., Sembenelli, A., 2006. Productivity, innovation and R\&D: Micro evidence for Italy. Europ. Econ. Rev. 50, 2037-2061.

Romer, P.M., 1986. Increasing Returns and Long-Run Growth. J. Polit. Economy. 94, 10021037.

Saal. D., 2001. A Constrained Translog Model of the Impact of Industrially and Federally Funded R\&D on U.S. Manufacturing Growth. RP0115, Aston Business School, Birmingham.

Verspagen. B., 1995. R\&D and Productivity: a Broad Cross-Section Cross-Country Look. J. Productiv. Anal. 6, 117-135. 
Wakelin, K., 2001. Productivity Growth and R\&S Expenditure in UK Manufacturing Firms. Res. Pol. 20, 1079-90.

Wooldridge, J.M., 2002. Econometric Analysis of Cross Section and Panel Data. MIT: Cambridge, MA. 